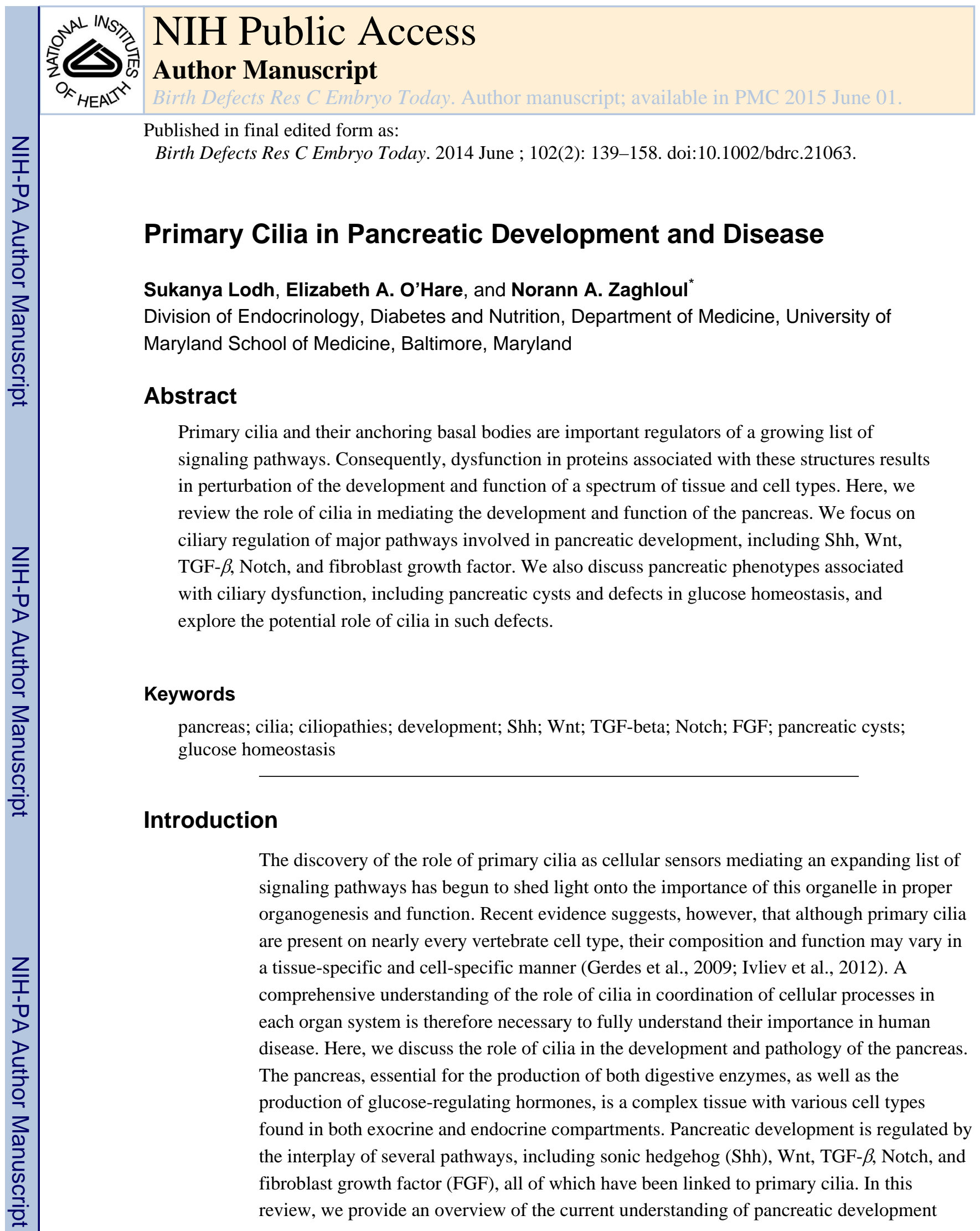

(C) 2014 Wiley Periodicals, Inc.

"Correspondence to: Norann A. Zaghloul, 660 W. Redwood Street, HH487, Baltimore, MD 21201.zaghloul@umaryland.edu. Sukanya Lodh and Elizabeth A. O'Hare contributed equally to this work

Conflict of Interest: The authors have no conflicts of interest to declare 
under the control of these pathways, offering insight into the role of primary cilia. We also discuss pancreatic phenotypes associated with ciliopathies and ciliary mutant models, providing mechanistic insights into the link between disruption of cilia and pancreatic pathology.

\section{Pancreatic Architecture and Development}

The mature pancreas comprises exocrine and endocrine compartments consisting of various cell types, approximately 15\% of which are ciliated (Table 1; (Kachar et al., 1979; Githens, 1988, 1994; Bonner-Weir, 2004). The exocrine tissue comprises approximately $99 \%$ of the organ and is composed of acinar and centroacinar cells arranged in glands that secrete digestive enzymes, including proteases, amylase, and lipase into the duodenum (Table 2). Ductal cells create a compartmentalized network consisting of the main duct and interlobular ducts connected to each other and to centroacinar cells, which link the network to acinar cells [(Reichert and Rustgi, 2011); reviewed in (Pan and Wright, 2011)]. Primary cilia have been identified on pancreatic ductal cells of the Chinese hamster, as well as centroacinar cells of the bat pancreas [(Boquist, 1968); D.W. Fawcett cited by (Sorokin, 1962)]. Interestingly, acinar cells are unique among exocrine cells, in that they are not ciliated (Cano et al., 2004; Ait-Lounis et al., 2007). The endocrine tissue, known as islets of Langerhans, is distributed throughout the organ and contains highly differentiated cell types including alpha $(\alpha)$, beta $(\beta)$, delta $(\delta)$, epsilon $(\varepsilon)$, and pancreatic polypeptide (PP) cells which are responsible for production and secretion of the hormones glucagon, insulin, somatostatin, ghrelin, and PP, respectively (Gittes, 2009; Pandol, 2011; Mansouri, 2012; Shih et al., 2013). In 1958, Munger (1958) first reported the presence of cilia on mouse pancreatic $\beta$-cells. These observations were later confirmed by electron microscopy in human $\beta$-cell tumor cells (Greider and Elliot, 1964). Primary cilia have since been reported on $\alpha$ - and $\delta$-cells of several vertebrates, including adult rats, mice, and rabbits (Yamamoto and Kataoka, 1986; Aughsteen, 2001), although they are absent from PP-cells (Cano et al., 2004; Ait-Lounis et al., 2007). It is unknown if $\varepsilon$-cells are ciliated (Table 1).

\section{DEVELOPMENT OF THE PANCREAS}

Pancreatic development begins early in embryogenesis, and is comprised of three major developmental processes: (1) formation and patterning of the endoderm, (2) specification of the pancreatic primordium, and (3) differentiation of exocrine and endocrine cell types. Patterning of the endoderm is initiated primarily through anterior-posterior (A-P) regionalization of the gut tube by concentration gradients of high FGF expression derived from the surrounding mesoderm and low levels of canonical Wnt signaling in the anterior endoderm, allowing for subsequent foregut specification (Kikuchi et al., 2000; Stafford and Prince, 2002; Jørgensen et al., 2007). FGF and TGF- $\beta$ signaling from the notochord suppress expression of sonic hedgehog (Shh) in the presumptive dorsal pancreatic epithelium, resulting in dorsal pancreatic bud formation (Jørgensen et al., 2007) and a similar process occurs in the ventral pancreatic epithelium. The pancreatic buds are comprised of pancreatic progenitor cells expressing $P d x l$, the broad pancreatic marker, as well as Ptfla, an important regulator of progenitor cell proliferation and acinar cell differentiation (Gu et al., 2002;

Burlison et al., 2008). The fusing of the dorsal and ventral pancreatic buds is followed by 
transition from the highly proliferative progenitor cell state to differentiation of exocrine and endocrine cell types, which marks the maturation of the pancreas. Those cells closest to the extracellular matrix, known as tip cells, are highest in exposure to mesenchymal FGF and acquire an acinar cell fate with activation of Wnt, Notch and Ptf1a, as well as downregulation of progenitor cell-maintaining factors. Cells within the trunk commit to either ductal or endocrine fates. These events are mediated by complex regulation of production and detection of signaling molecules. Although comprehensive reviews of pancreatic development have been presented elsewhere (Kim and Hebrok, 2001; GrapinBotton, 2008; Gittes, 2009; Tiso et al., 2009; Zorn and Wells, 2009; Pan and Wright, 2011; Pandol, 2011; Mansouri, 2012; Hegyi and Petersen, 2013; Shih et al., 2013), this discussion will focus on the role of cilia in these events through pathway regulation (Fig. 1).

\section{CILIARY REGULATION OF SIGNALING IN PANCREATIC DEVELOPMENT}

Sonic hedgehog (Shh)-Sonic hedgehog (Shh) is a secreted protein of the Hedgehog (Hh) family of ligands which, upon binding to their receptor Patched (PTCH), relieve its inhibition of Smoothened (SMO). Active SMO converts the Gli proteins from transcriptional repressors to transcriptional activators, driving expression of target genes (Nusslein-Volhard and Wieschaus, 1980; Ruppert et al., 1988; Hui et al., 1994; Marigo et al., 1996; AzaBlanc et al., 1997; Goodrich et al., 1997; Altaba, 1999; Sasaki et al., 1999; Schweitzer et al., 2000; Ingham and McMahon, 2001; McMahon et al., 2003; Ingham, 2008). Primary cilia are essential for proper Shh signaling in vertebrates. In the absence of ligand, PTCH1 is located at the base of the cilium and prevents ciliary entry of SMO (Corbit et al., 2005; Rohatgi et al., 2007). On ligand binding, PTCH1 exits the cilium, allowing SMO translocation to the ciliary membrane. The Gli transcription factors are also present in cilia, and their accumulation at the ciliary tip increases upon SMO activation correlating with transcriptional activation of Shh targets (Haycraft et al., 2005; Endoh-Yamagami et al., 2009; Kim et al., 2009b).

In the mouse embryo, Shh is expressed throughout the embryonic gut endoderm (Echelard et al., 1993; Bitgood and McMahon, 1995; Ramalho-Santos et al., 2000), but is exclusively excluded from the pancreatic bud endoderm, which expresses high levels of the pancreatic progenitor marker, $P d x l$ (Apelqvist et al., 1997; Hebrok et al., 1998; Hebrok et al., 2000). The repression of Shh in the dorsal pancreatic bud endoderm is mediated by notochordderived signals, namely the TGF- $\beta$ family member, activin- $\beta$ B , and FGFs (Kim et al., 1997a; Hebrok et al., 1998; Kim et al., 2000). Shh signaling in ventral pancreatic endoderm is suppressed by FGF from the cardiogenic mesenchyme (Deutsch et al., 2001). In mouse and chick, ectopic expression of Shh in embryonic pancreatic epithelium results in loss of $P d x I$ expression and subsequent transformation of pancreatic mesenchyme into gut mesoderm. Pancreatic endocrine and exocrine cells, however, develop but are mislocalized to the intestinal wall (Apelqvist et al., 1997; Hebrok et al., 1998). Similarly, while loss of Shh signaling does not impede development of the pancreas, it results in overproduction of endocrine cell types (Kim et al., 1997b; Hebrok et al., 2000). In human, Hh signaling components have been identified in the primary cilia of developing pancreatic duct cells. Hh signaling is also low during early pancreatic development, as human ductal cilia are devoid of Hh effectors, SMO and GLI2, at embryonic week 7.5. Both SMO and GLI2 gradually 
begin to accumulate in primary cilia at later stages between embryonic weeks 14 and 18 (Nielsen et al., 2008). Moreover, the presence of GLI3, whose expression is repressed by $\mathrm{Hh}$ signaling (Marigo et al., 1996; Buscher and Ruther, 1998; Schweitzer et al., 2000), is reduced gradually during pancreas development in the nucleus and cytoplasm of ductal epithelial cells (Nielsen et al., 2008), supporting the concept that in mammals, Hh signaling is repressed in early pancreatic progenitors and is required for both proliferation and maturation of the pancreas during later stages of development.

Given the central role of primary cilia in regulation of Shh, they have been implicated in key aspects of pancreatic development. Evidence suggests that primary cilia in pancreatic epithelium cells may block inappropriate activation of Hh signaling by regulating the GLI transcription factors (Cervantes et al., 2010). Overexpression of constitutively active GLI2 in transgenic mice [Pdxl-Cre;CLEG2 (di Magliano et al., 2006)] failed to completely activate the pathway in the pancreatic epithelium. Compounded with the loss of cilia in Pdx1-Cre;CLEG2;Kif3alox/lox, Ptch1 $1^{l a c Z /+}$ mice, however, the pathway was aberrantly activated, suggesting that the presence of primary cilia is necessary for impeding improper Hh activation in pancreas (Cervantes et al., 2010). Importantly, this regulation was downstream of Ptch1 and Smo, as elimination of cilia along with either did not significantly disrupt activation. The activation of $\mathrm{Hh}$ in this context did significantly disrupt pancreatic morphogenesis in 2-3 week old mice with a loss of differentiated exocrine cell types, primarily acinar cells, and an expansion of abnormal duct-like epithelial cells expressing markers of undifferentiated progenitor cells (Cervantes et al., 2010). Endocrine cell loss was also observed in these animals, likely due to postnatal cell death, suggesting the importance of primary cilia in maintaining reduced levels of Hh activation to allow differentiation of mature cell types (Cervantes et al., 2010).

The possibility that loss of cilia leads to loss of differentiation was supported by the observation that primary cilia-driven ectopic activation of Hh signaling in adult $\beta$-cells of $P d x 1-C r e^{E R} ; C L E G 2 ; K i f 3 a^{f f f}$ mice resulted in decreased insulin expression and secretion, as well as defects in glucose sensing (Landsman et al., 2011). This loss of $\beta$-cell functionality was due to their dedifferentiation. Further, the persistent Hh signaling ultimately transformed those cells to undifferentiated pancreatic tumors (Landsman et al., 2011). This finding was consistent with reports that elevated $\mathrm{Hh}$ signaling in cilia results in tumorigenesis. Cancer cells in human pancreatic ductal adenocarcinoma (PDAC) are devoid of cilia (Bailey et al., 2009; Seeley et al., 2009). Furthermore, these cells exhibit active Shh signaling and lack SMO, in contrast with the surrounding ciliated stromal cells, which was likely responsible for driving tumorigenesis as well as metastasis (Bailey et al., 2009). Consistent with this, cultured human PDAC cell lines, CFPAC-1 and PANC-1, are largely lacking in cilia, but those that are present exhibit less PTCH1 and very high levels of SMO, even in the absence of a Hh ligand (Nielsen et al., 2008). This suggests that either a lack of cilia or perhaps perturbed ciliary function results in activation of Hh signaling in the cancerous cell lines, and underscores the possibility that proper ciliary regulation of the pathway is required for maintenance of differentiated pancreatic cell fates.

Wnt-Wnt signaling molecules are secreted proteins that bind to Frizzled (Fz) transmembrane receptors and LRP5/ 6 coreceptors (Bhanot et al., 1996; YangSnyder et al., 
1996; Hsieh et al., 1999; Tamai et al., 2000; Umbhauer et al., 2000; Mao et al., 2001). The canonical pathway is characterized by recruitment of disheveled (Dsh) to the plasma membrane on Wnt binding, resulting in the cytoplasmic stabilization of $\beta$-catenin and its subsequent translocation to nucleus, where it directs target transcription in coordination with TCF/LEF (T cell-specific factor/lymphoid enhancer binding factor) transcription factors (Kioussi et al., 2002; Baek et al., 2003). In the absence of Wnt, $\beta$-catenin is phosphorylated and is degraded via proteasomes (He et al., 2004; Logan and Nusse, 2004). Studies suggest the presence of unphosphorylated $\beta$-catenin in cilia and phosphorylated $\beta$-catenin at the basal body (Corbit et al., 2008). In the absence of Wnt ligands, elevated levels of $\beta$-catenin have been observed in cells and organisms deficient in ciliary proteins, including KIF3A and $B B S 4$, potentially through a direct interaction of BBS4 with the proteasomal subunit RPN10, as well as a spatial relationship between proteasomes and this region of the cell (Wigley et al., 1999; Lin et al., 2003; Gerdes et al., 2007; Corbit et al., 2008). In addition, evidence suggests that the ciliary protein, inversin, is required for inhibition of canonical Wnt signaling by targeting Dsh for degradation (Simons et al., 2005). The canonical Wnt/ $\beta$ catenin pathway is therefore likely dependent on cilia for proper degradation of $\beta$-catenin and inhibiting aberrant activation.

During development of the pancreas, $\mathrm{Wnt} / \beta$-catenin signaling is critical from the earliest stages of endoderm patterning through differentiation of exocrine and endocrine cell types [reviewed in (Murtaugh, 2008)]. Initially, suppression of pathway expression is necessary in the anterior endoderm to maintain foregut identity (McLin et al., 2007). Consistent with this inhibitory role, ectopic $\mathrm{Wnt} / \beta$-catenin signaling during early pancreas development leads to complete pancreas agenesis in mice (Heller et al., 2002; Heiser et al., 2006). Wnt antagonists secreted from foregut endoderm repress the pathway in this region (Pilcher and Krieg, 2002; $\mathrm{Li}$ et al., 2008). This may be at least partially regulated by cilia, as expression of one Wnt antagonist, Sfrp5, is regulated by cilia. Depletion of cilia in Ift $88^{f l f l} \mathrm{fl}$ mice decreased Sfrp 5 expression with a concomitant upregulation of Wnt signaling and loss of $s r f p 5$ in zebrafish produced defects in endoderm-derived organogenesis, including impaired production of islets (Chang and Serra, 2013; Stuckenholz et al., 2013). After endodermal patterning, Wnt likely plays an inhibitory role in the pancreatic epithelium. Transgenic expression of a stabilized form of $\beta$-catenin in mice at around E10.5, when the buds emerge, leads to pancreas agenesis as a result of downregulation of FGF10 expression, upregulation of Shh signaling, and subsequent loss of $P d x 1$ expression (Heiser et al., 2006). In contrast, after the formation of pancreatic buds, Wnt is essential for proliferation of pancreatic progenitor cells, as well as for proliferation of newly specified acinar cells (Dessimoz et al., 2005; Murtaugh et al., 2005; Papadopoulou and Edlund, 2005; Heiser et al., 2006; Wells et al., 2007). This proliferative role is supported by the resulting pancreatic hypoplasia, largely affecting exocrine cells with some effects on islets when $\beta$-catenin signaling is perturbed in $P d x l$-expressing progenitors (Murtaugh et al., 2005; Papadopoulou and Edlund, 2005; Wells et al., 2007). Consistently, activated $\beta$-catenin prevents endocrine differentiation in chick (Pedersen and Heller, 2005), further supporting the proliferative role of the canonical Wnt pathway during the latter part of pancreatic specification. 
Though it remains to be elucidated how ciliary regulation of Wnt signaling may contribute to regulation of the developing pancreas, there is evidence of deregulated Wnt signaling in pancreatic cells lacking normal cilia. The developing pancreatic epithelium of the Ift 88 mutant oak ridge polycystic kidney (orpk) mouse was mostly devoid of cilia and the remaining cilia were smaller than normal (Cano et al., 2004). Further, the newborn orpk pancreas is characterized by acinar cell apoptosis, as well as ductal hyperplasia. Interestingly, pancreatic cells of orpk mice exhibited increased cytosolic $\beta$-catenin and transcription of TCF/LEF targets, suggesting the role of cilia in mediating levels of pancreatic Wnt signaling (Cano et al., 2004). In light of the importance of $\beta$-catenin signaling in mediating the balance between proliferation and differentiation in pancreatic cell types, these findings implicate the cilium in monitoring the levels of Wnt transduction to control that balance. Moreover, given that pancreatic development is marked by an absence of Wnt signaling in the ciliated endoderm and active Wnt in the proliferation of nonciliated acinar cells, cilia may serve to inhibit aberrant proliferation and drive differentiation.

TGF- $\beta$-Transforming growth factor $\beta$ (TGF- $\beta$ ) signaling is driven by binding of secreted growth factors of the TGF- $\beta$ superfamily to transmembrane serine/threonine kinase type I and type II receptors. Ligand binding results in tetramerization of two of each type of receptor and the subsequent phosphorylation and activation of the receptor I kinase domain by receptor II. The activated receptor phosphorylates receptor-regulated Smad (R-Smad) proteins which complex with comediator Smad (Co-Smad) proteins. The complex translocates to the nucleus where it mediates transcription of target genes. Inhibitory Smad (I-Smad) proteins negatively regulate the pathway by competitively binding to activated receptor or Co-Smad, I-Smad, or by targeting the receptor for degradation (Shi and Massague, 2003). In addition, TGF- $\beta$ receptors can be regulated by clathrin-dependent endocytosis in vesicles enriched in SMAD anchor for receptor activation (SARA), which recruits R-Smad for activation (Tang et al., 2010; Huang and Chen, 2012).

TGF- $\beta$ ligands are expressed in various regions of the developing pancreas, including the pancreatic epithelium, the surrounding mesenchyme, and both developing and mature islets (Ogawa et al., 1993; Feijen et al., 1994; Furukawa et al., 1995; Verschueren et al., 1995; Crisera et al., 1999; Tremblay et al., 2000; Dichmann et al., 2003). At early stages, the TGF$\beta$ superfamily protein, Activin-B, is secreted from the notochord, binds to ActR receptors in pancreatic endoderm, and represses expression of Shh in the foregut epithelium, promoting the specification of pancreatic progenitors (Kim and Hebrok, 2001; Kim and MacDonald, 2002; Johansson and Grapin-Botton, 2002; Hebrok, 2003). ActR receptors are also expressed in the islets (Yamaoka et al., 1998; Shiozaki et al., 1999; Kim et al., 2000; Goto et al., 2007). The ActR ligand Activin-B is also expressed in the glucagon positive $a$-cells during early mouse development (E12.5) and later (E18.5) in differentiated islets (Maldonado et al., 2000), suggesting a role of Activin signaling in lineage specification (Ritvos et al., 1995). It is therefore not surprising that mutations in ActR or its mediator, Smad2, result in reduced islet in mice (Yamaoka et al., 1998; Kim et al., 2000; Goto et al., 2007) or that overexpression of Smad7, an inhibitor of the pathway, also leads to reduction in $\beta$-cell mass (Smart et al., 2006). Likewise, another TGF- $\beta$ inhibitor, follistatin, which is expressed in the mesenchyme during early developmental stages (before E12.5) and in 
differentiated islets at E18.5, inhibits endocrine differentiation while also promoting the specification of exocrine tissue (Miralles et al., 1998). These findings suggest a role for TGF- $\beta$ signaling in driving endocrine tissue production, while inhibiting exocrine fates. However, another TGF- $\beta$ ligand, GDF11, may actually inhibit endocrine development (Harmon et al., 2004). Therefore, although the complete role of various TGF- $\beta$ ligands and receptors in achieving the balance between exocrine and endocrine fates remains to be elucidated, the pathway is clearly integral to both early and late stages of pancreatic development.

Recent evidence has implicated primary cilia in the regulation of TGF- $\beta$ signaling, suggesting that the cilium may serve as an intracellular site in which signaling components are brought together. The ciliary pocket region is a unique site for endocytosis; both early endosomes and clathrin-dependent endocytic vesicles are enriched in this region (Poole et al., 1985; Molla-Herman et al., 2010; Rattner et al., 2010; Ghossoub et al., 2011). As such, the fact that TGF- $\beta$ receptor internalization via clathrin-coated pits enhances the signaling by sequestering the receptors and R-Smads (Tang et al., 2010; Huang and Chen, 2012) suggests a possible role for cilia in regulation of the signaling components. Indeed, TGF- $\beta$ RI and TGF- $\beta$ RII are located at the ciliary tip and, on activation, are trafficked to the base of the cilium where they activate Smad2/3 (Clement et al., 2013). Smad4, which is also located at the ciliary base, complexes with phosphorylated Smad2/3 and translocates to nucleus (Clement et al., 2013). This process is dependent on the presence of a cilium, as embryonic fibroblasts of the orpk mouse, which exhibit shorter cilia (Schneider et al., 2005; Corbit et al., 2008), express similar levels of TGF- $\beta$ RI and TGF- $\beta$ RII, but reduced clathrin dependent endocytosis and reduced localization of the receptors and $\mathrm{pSmad} 2 / 3$ at the base of cilium, correlating with a reduction in pathway activation (Clement et al., 2013). While this implicates a dependence on cilia for proper TGF- $\beta$ signaling, its role in pancreatic development remains unclear. Pancreatic architecture in the orpk mouse begins to be disrupted late in gestation, but is primarily characterized by loss of exocrine cell types with no effect on islets (Cano et al., 2004; Zhang et al., 2005), consistent with a possible role for the pathway in maintaining the balance between both compartments. Given the multiple roles of TGF- $\beta$ at both early and late stages of pancreatic development, it will be necessary to investigate perturbation of cilia at discrete developmental time points to delineate their role in mediating TGF- $\beta$ regulation of pancreatic phenotypes.

Notch-Transmembrane Notch receptors are bound and activated by ligands of the delta Jagged family proteins present on the surface of neighboring cells. Binding results in sequential proteolytic cleavages of the receptor, which ultimately produces a Notch intracellular domain (NICD) fragment that translocates to the nucleus to drive transcription of target genes (Artavanis-Tsakonas et al., 1999; Radtke and Raj, 2003; Schweisguth, 2004). Notch receptors are expressed in pancreatic epithelium as well as mesenchymal and endothelial cells (Lammert et al., 2000), and signaling suppresses differentiation and induces proliferation in pancreatic progenitors (Ahnfelt-Ronne et al., 2007; Fujikura et al., 2007). Similarly, in mouse, this balance is dictated by expression of $H E S$ genes under the control of nuclear NICD bound to the DNA-binding protein, RBP-J $\kappa$, which inhibit expression of $\mathrm{Ngn}$ transcription factors (Lewis, 1996; Ma et al., 1996; Sommer et al., 1996; Beatus and 
Lendahl, 1998). Ngn3, in particular, is expressed in the pancreatic progenitor cells and commits them to endocrine fates (Gu et al., 2002; Herrera et al., 2002). Notch, therefore, promotes exocrine fates by enhancing expression of its target, Hes 1 , which at the same time inhibits endocrine differentiation via suppression of $\mathrm{Ngn3}$ during early pancreas development (Jensen et al., 2000). Consistently, loss of Notch signaling in early pancreatic development results in precocious differentiation of endocrine cells at the expense of ductal cells (Jensen et al., 2000; Parsons et al., 2009). Although the detailed mechanism is unclear, it has been suggested that $N g n 3$ may direct expression of the Notch ligand, Dll1, resulting in NICD-dependent transcription of Hes 1 in neighboring cells which, in turn, inhibits Ngn3 and promotes the exocrine fate (Gasa et al., 2004; Wang et al., 2010). Later, after the establishment of $\mathrm{Ngn3}+$ progenitor cells, Notch signaling is important for differentiation of endocrine fates (Cras-Meneur et al., 2009). The level of Notch signaling also determines the ductal or endocrine fate of trunk cells by regulating both positive (Sox9) and negative (Hes 1) regulators of $\mathrm{Ngn} 3$ (Shih et al., 2012). High Notch signaling results in the expression of both Hesl and Sox9, and gives rise to a ductal lineage. By contrast, low levels of Notch results in the expression of only Sox9 and differentiation of endocrine cells (Shih et al., 2012).

Ciliary regulation of Notch signaling is not well understood and appears to be tissuedependent. Discrepant effects on Notch have been reported with ablation of cilia in the pancreas and other tissues, namely developing skin epithelium. Deletion of Kif3a in the suprabasal cells in embryonic mouse skin impedes Notch signaling, resulting in defective skin development (Ezratty et al., 2011). In these cells, the Notch 3 receptor localizes to the cilium and, Presenilin-2, the $\gamma$-secretase component catalyzing NICD cleavage, localizes to the basal body, indicating a direct dependence of Notch on the primary cilium. By contrast, depletion of cilia in developing pancreas via elimination of Kif3a gene in a transgenic mouse model (Pdxl-Cre; CLEG2; Kif3alox/lox, Ptchl ${ }^{l a c Z /+}$ ) resulted in the upregulation of Notch pathway with an increase in Hesl expression (Cervantes et al., 2010). While these discrepant findings suggest the likelihood of tissue- and stage-dependent ciliary regulation of Notch, the finding that loss of cilia results in increased signaling in the pancreas (Cervantes et al., 2010) suggests that, similar to Shh and Wnt signaling, proper ciliary function is necessary to maintain Notch signaling below a certain threshold of activation. Indeed, loss of ciliopathy proteins results in increased activation of the pathway in zebrafish embryos and multiple cell lines (Leitch et al., 2014; Liu et al., 2014). This would be consistent with the perturbation of exocrine fates in the absence of cilia, without major consequences for endocrine cells (Cano et al., 2004; Zhang et al., 2005). In addition to ciliary regulation of Notch, Notch also regulates formation of cilia and ciliary length. For example, Notch regulates the length of cilia in Kupffer's vesicle in association with ligand DeltaD in zebrafish. Shorter cilia are produced in the absence of Notch signaling and hyperactive signaling leads to longer cilia (Lopes et al., 2010). In the pancreas, the Notch target genes, Sox9 and Tcf2, control ciliogenesis (Gresh et al., 2004; Zong et al., 2009; Shih et al., 2012). Interestingly, Sox9-deficient mice exhibit decreased $P k d 2$ expression, reduced number of cilia in the pancreatic epithelium, and ductal lumen as well as development of pancreatic cysts (Shih et al., 2012). Given that loss of $T c f 2$ leads to formation of cysts in the kidney (Gresh et al., 2004), this Notch effector may play a similar role in mediating ciliogenesis in the pancreas. Although this intricate mechanism of feedback is yet to be 
clearly established, evidence suggests that cilia regulate the level of Notch in the developing pancreas and that Notch in turn regulates primary cilia, maintaining a proper threshold of signaling.

FGF-FGFs are extracellular ligands that bind to the extracellular domain of FGF receptors (FGFRs), a family of tyrosine kinase receptors, in combination with heparan sulphate.

Binding of two FGF molecules along with one or two heparan sulfate proteoglycans results in receptor dimerization, which leads to conformational changes and cross phosphorylation of tyrosine residues in the intracellular domain of the receptors. This triggers several different signaling pathways, such as, the Ras/ERK pathway, the Akt pathway, and the protein kinase C (PKC) pathway (Schlessinger, 2000; Dailey et al., 2005; Mohammadi et al., 2005).

Secreted from the surrounding mesenchyme, FGFs are critical regulators of the pancreatic epithelium proliferation and differentiation. FGFs secreted from notochord and cardiogenic mesenchyme suppress Shh signaling in dorsal and ventral pancreatic endoderm, respectively (Kim et al., 1997a; Hebrok et al., 1998; Deutsch et al., 2001). Pdxl expression in pancreatic progenitors is initiated by Fgf2 and Fgf10 in mice (Le Bras et al., 1998; Bhushan et al., 2001). The default programming of epithelium in the absence of mesenchymal signals is toward islets, but the mesenchymal interaction leads to exocrine differentiation (Gittes et al., 1996; Miralles et al., 1998). FGF7, for example, binds to FGFR2IIIb, activating proliferation in the pancreatic epithelium, and repressing endocrine differentiation (Zhang et al., 2006). Removal of Fgf7 results in differentiation of endocrine cells (Elghazi et al., 2002). Similarly, Fgf10, a high affinity ligand for FGFR2b, is highly expressed in the mesenchyme surrounding the pancreatic buds during the early stages of development (Bhushan et al., 2001), with decreased expression in the pancreatic epithelium at later developmental stages (Hart et al., 2003). Persistent expression of FgflO in the developing pancreatic epithelium of transgenic mice leads to pancreatic hyperplasia as a result of increased proliferation of pancreatic epithelial cells and perturbed differentiation of endocrine cells (Hart et al., 2003). Likewise, mice lacking FGFR2b signaling, due to lack of FGFR2b or FGF10 develop pancreatic hypoplasia (Celli et al., 1998; Ohuchi et al., 2000; Bhushan et al., 2001; Revest et al., 2001). FGF10 promotes pancreatic progenitor proliferation by inducing $P d x l$ expression and maintaining Ptfla expression; these cells fail to proliferate in the absence of FGF10 (Bhushan et al., 2001; Hart et al., 2003; Norgaard et al., 2003; Jacquemin et al., 2006). Although the role of FGF signaling in mediating early proliferative and progenitor capacity is critical, the downstream cascade by which this occurs is not completely understood.

One possible mechanism by which FGF participates in pancreatic specification is through its regulation of ciliogenesis. FGF regulates the length of primary cilia and, therefore, ciliary function. In zebrafish, Fgf8 and Fgf24 activate Fgfr1 and regulate the expression of foxj1 and $r f x 2$, transcription factors known to play significant roles in ciliogenesis (Brody et al., 2000; Bonnafe et al., 2004; Neugebauer et al., 2009). These factors activate intraflagellar transport genes such as ift 88 (Neugebauer et al., 2009). Consistently, suppression of $F g f r l$ in zebrafish leads to reduced ciliary length in Kupffer's vesicle (Neugebauer et al., 2009), as does suppression of FGF8 and downstream effectors, ler2 and fibpl (Hong and Dawid, 2009). Therefore, it is possible that FGF signaling is necessary for proper production of the 
cilium, which coordinates the intricate balance of pathways required for proper pancreatic development. For example, FGF10 maintains Notch signaling and Hes 1 expression in developing pancreas (Hart et al., 2003; Norgaard et al., 2003; Miralles et al., 2006), and sustained expression of Fgf10 in transgenic mice inhibits $\mathrm{Ngn} 3$ expression within pancreatic epithelium as a result of active Notch, ultimately impeding pancreatic cell differentiation (Hart et al., 2003). Therefore, Notch signaling acts as a downstream mediator of FGF10 signaling in pancreatic precursor cells (Miralles et al., 2006), potentially through primary cilia. Similarly, FGF is necessary for proper regulation of other pathways, including Shh and Wnt signaling. In light of the important role of cilia in regulation of these pathways, it is possible that FGF mediates the availability of cilia to regulate them, a possibility that remains to be explored.

\section{PANCREATIC PHENOTYPES ASSOCIATED WITH CILIARY DYSFUNCTION}

Defects in cilia have been associated with a spectrum of human diseases collectively called ciliopathies (Badano et al., 2006). While each clinical entity is characterized by discrete genetic mutations and phenotypes, overlap in both is prevalent across the diseases. These include renal cysts, retinal degeneration, laterality defects, and polydactyly (Beales and Kenny, 2014). Defects of the pancreas, however, have been less well-characterized, although they have been described in many ciliopathies. Dysplasia and fibrosis of the pancreas and liver have been reported in patients harboring mutations in genes associated with nephronopthisis (NPH), including mutations in NEK8/NPHP9 and NPHP3 (Bergmann et al., 2008; Frank et al., 2013). Fibrocystic disease of the pancreas has also been reported in oral-facial-digital syndrome type 1 (OFD1), Jeune asphyxiating thoracic dystrophy, and renal-hepatic-pancreatic dypslasia (Bernstein et al., 1987; Yerian et al., 2003; Chetty-John et al., 2010; Ware et al., 2011). The more prominent pancreatic feature of ciliopathies is the presence of ductal cysts. Pancreatic cysts have been reported in about $10 \%$ of patients diagnosed with autosomal dominant polycystic kidney disease (ADPKD), the most common ciliopathy (Fick et al., 1995; Torra et al., 1997; Nicolau et al., 2000; Igarashi and Somlo, 2002). In contrast, about $70 \%$ of patients with von Hippel-Lindau disease (VHL), an atypical ciliopathy and inherited tumor syndrome caused by mutations in the VHL tumor suppressor gene, exhibit pancreatic cysts of varying severity, including simple cysts, serous cystadenomas, and neuroendocrine tumors (Latif et al., 1993; Lolkema et al., 2008; van Asselt et al., 2013). In spite of these multiple reports of pancreatic structural lesions, exocrine or endocrine functional defects are often not detected. The exception is Alstrom syndrome, in which $\beta$-cell dysfunction and major defects in glucose regulation are hallmarks of disease (Marshall et al., 2011). This is in contrast with another obesity ciliopathy, BardetBiedl Syndrome (BBS), in which patients appear to be relatively protected from defects in $\beta$ cell function and glucose homeostasis (Lee et al., 2011; Marion et al., 2012). As such, clinical evidence suggests that defects in cilia are directly responsible for pancreatic structural and functional phenotypes. Here, we discuss the potential role of cilia in the development and onset of the more prominent pancreatic defects associated with ciliopathies: pancreatic cysts and disruption of glucose regulation. 


\section{PANCREATIC CYSTS}

Pancreatic cysts are a heterogenous group of lesions with little known about the origin, pathophysiology, and developmental processes involved. Pancreatic cysts can present with pancreatitis, cystic kidney disease, or alone (Pirro et al., 2003; Khokhar and Seidner, 2004), and can be divided into two categories: benign and neoplastic. Cysts likely result from the abnormal proliferation of a single epithelial cell which eventually expands until it pinches off as an isolated pancreatic cyst, continually expanded by fluid secreted into the cyst lumen (Grantham, 2000; Calvet and Grantham, 2001). Cysts of the pancreas are often accompanied by other phenotypes, including increased proliferation of epithelial cells, acinar cell apoptosis, and dilation of ducts.

The mechanisms by which primary cilia regulate the production of pancreatic cysts are unclear, but substantial evidence from animal models indicates that loss of cilia can lead to their development. For example, perturbation of cilia of the exocrine ductal and centroacinar cells results in pancreatic cyst formation (Cano et al., 2006; Gallagher et al., 2008; Seeley et al., 2009; van Asselt et al., 2013). Defects in cilia in the orpk mouse, lacking expression of the Ift88/Polaris gene which is necessary for ciliary assembly (Pazour et al., 2000; Taulman et al., 2001; Yoder et al., 2002), results in expansion of developing and postnatal ducts, giving rise to cystogenesis (Cano et al., 2004). Interestingly, this ductal expansion is accompanied by apoptosis in the only non-ciliated exocrine cell type, acinar cells, resulting in an overall loss of exocrine tissue and pancreas size (Cano et al., 2004; Zhang et al., 2005). This is consistent with the ductal dilation observed during development and postnatal expansion of animals with a conditional loss of cilia in pancreatic tissue induced by $P d x I$ Cre $e^{e a r l y}$;Kif3af/ $f$ (Cano et al., 2006). Although both the ductal and endocrine cells were deciliated in those mice, lineage tracing showed that the cysts originated from the ciliated ductal cells. As the mice aged, the pancreatic pathophysiology progressed to loss of acinar tissue, fluid filled cysts, extensive dilation of ductal systems, increasing adipose tissue mass, and eventual fibrosis (Cano et al., 2006). Likewise, loss of $V h l$ specifically in pancreas gave rise to postnatal development of cysts and microcystic adenoma (Shen et al., 2009). Similar observations were reported from mutant mice deficient for hepatocyte nuclear factor 6 (HNF-6), a transcription factor expressed in the pancreatic progenitor cells regulating $P d x I$ expression and the differentiation to ductal cells (Pierreux et al., 2006; Zhang et al., 2009). Loss of Hnf6 expression resulted in an absence of primary cilia from pancreatic ducts, producing enlargement of the lumen and multiple cysts (Kaestner, 2006; Pierreux et al., 2006). HNF6 is believed to play an important role in controlling the expression of $P k h d l$ through HNF1 and Cys 1 (cystin), thereby regulating the formation of primary cilia (Gresh et al., 2004; Kaestner, 2006; Pierreux et al., 2006). In addition to loss of cilia, impaired ciliary function can also lead to pancreatic cyst formation. Pkd2 and inversin (Invs) are two ciliary proteins that are not required for cilia formation, but mediate cilia function (Wu et al., 2000; Morgan et al., 2002; Kim et al., 2009a). Similar to animals lacking cilia, mice mutated for $P k d 2$ and Invs exhibit increased ductal structures and reduced acinar tissue (Cano et al., 2004). Similarly, mice lacking the gene implicated in ADPKD, $P k d l$, exhibit pancreatic ductal cysts (Lu et al., 1997). 
The mechanistic links between primary cilia in pancreas and cystogenesis remain elusive, although it has been proposed that they may function as mechanosensors in the pancreatic ductal cells to measure luminal flow similar to what has been observed in kidney cells (Ong and Wheatley, 2003; Nauli et al., 2003; Nauli and Zhou, 2004). It is possible that the absence of cilia would impede sensing of luminal flow, resulting in increased pressure and defects in other cellular regulatory signals driving proliferation, differentiation, and apoptosis, ultimately giving rise to cystogenesis. Another possibility is the involvement of microtubule defects associated with loss of ciliary proteins. For example, the VHL protein binds to KIF3A and KAP3 (kinesin-associated protein 3) (Lolkema et al., 2007), but also plays a significant role in ciliary maintenance and stability through its regulation of cell polarity, assembly of the extracellular matrix, and microtubule stability (Esteban et al., 2006; Lutz and Burk, 2006; Schermer et al., 2006). Mutant VHL-induced microtubule instability gives rise to the development of cysts in renal tissue (Esteban et al., 2006) and it is plausible that similar mechanisms may be responsible for the development of pancreatic cysts in VHL.

It is also likely that disruption of signaling as a result of ciliary dysfunction may result in production of cysts either through polarization defects or dedifferentiation that result in aberrant proliferation. HNF-6 deficient mice, for example, exhibit disrupted polarization of ductal epithelial cells as well as mislocalization of $\beta$-catenin from the lateral membrane (Pierreux et al., 2006), suggesting a possible role for Wnt signaling and downstream regulation of proliferation. Additionally, the cystic epithelium of Pdxl-Cre early;-Kif3af/f mice expressed high levels of TGF- $\beta$ ligands, as well as phosphorylated extracellular-signalregulated kinase (ERK), indicating MEK/ERK pathway activation (Cano et al., 2006). These pathways are highly implicated in pancreatic fibrosis and neoplastic transformation (Lee et al., 1995; Sanvito et al., 1995; Hezel et al., 2006), suggesting the possibility of similar pathway deregulation in cilia-driven cystogenesis. Likewise, aberrant activation of Shh signaling may be implicated, given that $\beta$-cell specific disruption of cilia and elevation of Shh results in dedifferentiation and aberrant proliferation (Landsman et al., 2011). Similar to the role of cilia during development in inhibiting activation of morphogenetic pathways, it is possible that continual disruption or postnatal ablation of cilia activates those pathways driving proliferative cystogenesis.

\section{IMPAIRED GLUCOSE REGULATION}

Disruption of glucose homeostasis in ciliopathies has been discussed primarily in the context of the subgroup of diseases characterized by highly penetrant obesity, which include BardetBiedl syndrome (BBS) and Alstrom syndrome. A majority of BBS and Alstrom patients are obese, potentially as a result of centrally mediated hyperphagia (Arsov et al., 2006; Lee et al., 2009; Sherafat-Kazemzadeh et al., 2013), and display complications associated with obesity including hypertension, hyperlipidemia, and hyperleptinemia (Beales et al., 1999; Grace et al., 2003; Feuillan et al., 2011; Girard and Petrovsky, 2011). Despite the similarities between the two disorders, the rate of early onset of diabetes is significantly higher in Alstrom patients (Marshall et al., 2005; Marshall et al., 2007; Girard and Petrovsky, 2011) when compared to most cohorts of BBS patients (Beales et al., 1999; Grace et al., 2003; Feuillan et al., 2011), as well as to rates of diabetes in common obesity 
(Mokdad et al., 2003; Finkelstein, 2008; Bettini et al., 2012). Although this is in large part due to the severe insulin resistance in children afflicted with Alstrom (Marshall et al., 2005) which is not as prevalent in BBS (Beales et al., 1999; Grace et al., 2003; Feuillan et al., 2011), there is evidence to support a role for dysfunction of the endocrine pancreas, namely $\beta$-cells. Clinical reports suggest that the progression of diabetes in Alstrom patients is due to failure in insulin secretion from $\beta$-cells, without any further worsening of insulin resistance (Green et al., 1989; Moore et al., 2005). Consistent with this possibility, the protein product of the gene mutated in Alstrom, ALMS1, is highly expressed in adult and fetal pancreatic islets (Hearn et al., 2005; Li et al., 2007) and loss of Almsl expression in mutant mice results in pancreatic hyperplasia, partial degranulation of $\beta$-cells, and islet cysts (Collin et al., 2005; Arsov et al., 2006). The extent to which Alms 1 -deficient $\beta$-cells are able to respond to glucose and secrete insulin is unknown. In contrast, insulin secretion increased in C. elegans models of BBS and cultured mouse insulinoma cells (Min6), an in vitro model for $\beta$-cells, exhibited enhanced insulin secretion in the absence of $B b s$ gene expression (Lee et al., 2011). Consistently, mouse models of BBS exhibit increased insulin sensitivity and normal glucose management (Marion et al., 2012). These findings suggest that ciliary proteins may play discrepant roles in the regulation of $\beta$-cell function or, potentially, the cilium maintains a delicate balance between enhanced and depleted $\beta$-cell function.

Although little is known about the role of BBS and Alstrom proteins per se, there is evidence to suggest that cilia in general are important in $\beta$-cell differentiation and function. $R f x 3$, a transcription factor necessary for ciliogenesis (Bonnafe et al., 2004), is expressed in $\mathrm{Ngn} 3+$ endocrine progenitor cells in the developing mouse pancreas as well as in differentiated endocrine cells, including $\beta$-cells (Ait-Lounis et al., 2007). Mice deficient in this transcription factor possess fewer $\beta$-cells, $\alpha$-cells, and $\varepsilon$-cells during perinatal stages. Furthermore, the adult mice exhibit smaller islets, decreased insulin production, reduced glucose stimulated insulin secretion, and impaired glucose tolerance (Ait-Lounis et al., 2007). Assessment of developing $R f x 3^{-/-}$mice revealed abnormal $\beta$-cell development at E15.5, indicated by the presences of accumulated $\beta$-cell precursors and defective $\beta$-cells expressing decreased Insulin, Glut2, and Glucokinase (Ait-Lounis et al., 2010). Consistent with the role of $R f x 3$ in ciliogenesis, the endocrine cells of $R f x 3^{-/-}$mice also exhibited reduced and shortened primary cilia (Ait-Lounis et al., 2007), suggesting an important role of cilia in the development and maintenance of endocrine cells as well as in the maintenance of normal glucose homeostasis. This potential role is supported by the loss of $\beta$-cell differentiation when cilia are ablated specifically in $\beta$-cells, along with increased Shh signaling (Landsman et al., 2011). Although further investigation is required to determine the exact role of cilia and ciliopathy proteins in the function and maintenance of $\beta$-cells and other endocrine cell types, the emerging evidence suggests that disruption of glucose regulation in ciliopathies_-and potentially in more common diseases-may be directly linked to the regulation of signaling that is highly dependent on cilia and is critical to proper pancreatic morphogenesis.

\section{Conclusions}

Primary cilia have been established as important mediators of many developmental signaling pathways and the developing pancreas is highly reliant on pathways that have been clearly 
linked to cilia including Shh, Wnt, FGF, Notch, and TGF- $\beta$. It is therefore not surprising that disruption of cilia gives rise to disruption of both pancreatic morphology and function. However, the extent to which pancreatic morphogenesis and homeostasis is reliant on ciliary function to maintain proper signaling is unknown. Furthermore, the involvement of cilia in regulation of other pathways necessary for pancreatic development, such as retinoic acid signaling, is unclear. Future studies investigating the specific role in pancreas played by proteins associated with cilia and ciliopathies will be necessary not only to clarify the extent to which cilia can be linked to pancreatic phenotypes but also to achieve a more complete understanding of pancreatic development and function in general.

\section{Acknowledgments}

Supported by a grant from the National Institutes of Health [K01DK092402 (N.A.Z.) and T32AG000219 (E.A.O.)]

\section{References}

Ahnfelt-Ronne J, Hald J, Bodker A, et al. Preservation of proliferating pancreatic progenitor cells by Delta-Notch signaling in the embryonic chicken pancreas. BMC Dev Biol. 2007; 7:63. [PubMed: 17555568]

Ait-Lounis A, Baas D, Barras E, et al. Novel function of the ciliogenic transcription factor RFX3 in development of the endocrine pancreas. Diabetes. 2007; 56:950-959. [PubMed: 17229940]

Ait-Lounis A, Bonal C, Seguin-Estevez Q, et al. The transcription factor Rfx3 regulates beta-cell differentiation, function, and glucokinase expression. Diabetes. 2010; 59:1674-1685. [PubMed: 20413507]

Altaba ARI. Gli proteins encode context-dependent positive and negative functions: implications for development and disease. Development. 1999; 126:3205-3216. [PubMed: 10375510]

Andralojc KM, Mercalli A, Nowak KW, et al. Ghrelin-producing epsilon cells in the developing and adult human pancreas. Diabetologia. 2009; 52:486-493. [PubMed: 19096824]

Apelqvist A, Ahlgren U, Edlund H. Sonic hedgehog directs specialised mesoderm differentiation in the intestine and pancreas. Curr Biol. 1997; 7:801-804. [PubMed: 9368764]

Arsov T, Silva DG, O'Bryan MK, et al. Fat Aussie-a new Alstrom syndrome mouse showing a critical role for ALMS1 in obesity, diabetes, and spermatogenesis. Mol Endocrinol. 2006; 20:1610 1622. [PubMed: 16513793]

Artavanis-Tsakonas S, Rand MD, Lake RJ. Notch signaling: cell fate control and signal integration in development. Science. 1999; 284:770-776. [PubMed: 10221902]

Aughsteen AA. The ultrastructure of primary cilia in the endocrine and excretory duct cells of the pancreas of mice and rats. Eur J Morphol. 2001; 39:277-283. [PubMed: 12221509]

AzaBlanc P, RamirezWeber FA, Laget MP, et al. Proteolysis that is inhibited by Hedgehog targets Cubitus interruptus protein to the nucleus and converts it to a repressor. Cell. 1997; 89:1043-1053. [PubMed: 9215627]

Badano JL, Mitsuma N, Beales PL, Katsanis N. The ciliopathies: an emerging class of human genetic disorders. Annu Rev Genomics Hum Genet. 2006; 7:125-148. [PubMed: 16722803]

Baek SH, Kioussi C, Briata P, et al. Regulated subset of G1 growth-control genes in response to derepression by the Wnt pathway. Proc Natl Acad Sci USA. 2003; 100:3245-3250. [PubMed: 12629224]

Bailey JM, Mohr AM, Hollingsworth MA. Sonic hedgehog paracrine signaling regulates metastasis and lymphangiogenesis in pancreatic cancer. Oncogene. 2009; 28:3513-3525. [PubMed: 19633682]

Barth, B.; Burdick, J. Anatomy, histology, embryology, and developmental anomalies of the pancreas. In: Feldman, M.; Friedman, L.; Brandt, L., editors. Sleisenger and Fordtran's gastrointestinal and liver disease: Pathophysiology/diagnosis/management. 9. Philadelphia, PA: Saunders, An Imprint of Elsevier Inc; 2010. p. 909-919. 
Beales, P.; Kenny, T. Towards the diagnosis of a ciliopathy. In: Kenny, T.; Beales, P., editors. Ciliopathies: A reference for clinicians. Oxford University Press New York; New York: 2014. p. $1-7$.

Beales PL, Elcioglu N, Woolf AS, et al. New criteria for improved diagnosis of Bardet-Biedl syndrome: results of a population survey. J Med Genet. 1999; 36:437-446. [PubMed: 10874630]

Beatus P, Lendahl U. Notch and neurogenesis. J Neurosci Res. 1998; 54:125-136. [PubMed: 9788272]

Bergmann C, Fliegauf M, Bruchle NO, et al. Loss of nephrocystin-3 function can cause embryonic lethality, Meckel-Gruber-like syndrome, situs inversus, and renal-hepatic-pancreatic dysplasia. Am J Hum Genet. 2008; 82:959-970. [PubMed: 18371931]

Bernstein J, Chandra M, Creswell J, et al. Renal-Hepatic-Pancreatic dysplasia - A syndrome reconsidered. Am J Med Genet. 1987; 26:391-403. [PubMed: 3812591]

Bettini V, Maffei P, Pagano C, et al. The progression from obesity to type 2 diabetes in Alstrom syndrome. Pediatr Diabetes. 2012; 13:59-67. [PubMed: 21722283]

Bhanot P, Brink M, Samos CH, et al. A new member of the frizzled family from Drosophila functions as a wingless receptor. Nature. 1996; 382:225-230. [PubMed: 8717036]

Bhushan A, Itoh N, Kato S, et al. Fgf10 is essential for maintaining the proliferative capacity of epithelial progenitor cells during early pancreatic organogenesis. Development. 2001; 128:5109_ 5117. [PubMed: 11748146]

Bitgood MJ, McMahon AP. Hedgehog and bmp genes are coexpressed at many diverse sites of cellcell interaction in the mouse embryo. Dev Biol. 1995; 172:126-138. [PubMed: 7589793]

Bonal C, Herrera PL. Genes controlling pancreas ontogeny. Int J Dev Biol. 2008; 52:823-835. [PubMed: 18956314]

Bonnafe E, Touka M, AitLounis A, et al. The transcription factor RFX3 directs nodal cilium development and left-right asymmetry specification. Mol Cell Biol. 2004; 24:4417-4427. [PubMed: 15121860]

Bonner-Weir, S. Islets of langerhans: Morphology and post-natal growth. In: Kahn, CR.; Smith, RJ.; Jacobson, AM.; Weir, GC.; King, EL., editors. Joslin's diabetes mellitus. 14. Philadelphia, PA: Lippincott Williams and Wilkins; 2004. p. 41-52.

Boquist L. Cilia in normal and regenerating islet tissue. An utlrastructural study in the Chinese hamster with particular reference to the B-cells and the ductular epithelium. Z Zellforsch mikrosk Anat. 1968; 89:519-532.

Bouwens L, Rooman I. Regulation of pancreatic beta-cell mass. Physiol Rev. 2005; 85:1255-1270. [PubMed: 16183912]

Brody SL, Yan XH, Wuerffel MK, et al. Ciliogenesis and left-right axis defects in forkhead factor HFH-4-null mice. Am J Respir Cell Mol Biol. 2000; 23:45-51. [PubMed: 10873152]

Buffa R, Capella C, Solcia E, et al. Vasoactive intestinal peptide (VIP) cells in the pancrease and gastrointestinal mucosa. An immunohistochemical and ultrastructural study. Histochemistry. 1977; 50:217-227. [PubMed: 319084]

Burlison JS, Long Q, Fujitani Y, et al. Pdx-1 and Ptf1a concurrently determine fate specification of pancreatic multipotent progenitor cells. Dev Biol. 2008; 316:74-86. [PubMed: 18294628]

Buscher D, Ruther U. Expression profile of Gli family members and Shh in normal and mutant mouse limb development. Dev Dyn. 1998; 211:88-96. [PubMed: 9438426]

Calvet JP, Grantham JJ. The genetics and physiology of polycystic kidney disease. Sem Nephrol. 2001; 21:107-123.

Cano DA, Murcia NS, Pazour GJ, Hebrok M. Orpk mouse model of polycystic kidney disease reveals essential role of primary cilia in pancreatic tissue organization. Development. 2004; 131:34573467. [PubMed: 15226261]

Cano DA, Sekine S, Hebrok M. Primary cilia deletion in pancreatic epithelial cells results in cyst formation and pancreatitis. Gastroenterology. 2006; 131:1856-1869. [PubMed: 17123526]

Celli G, LaRochelle WJ, Mackem S, et al. Soluble dominant-negative receptor uncovers essential roles for fibroblast growth factors in multi-organ induction and patterning. Embo J. 1998; 17:16421655. [PubMed: 9501086] 
Cervantes S, Lau J, Cano DA, et al. Primary cilia regulate Gli/Hedgehog activation in pancreas. Proc Natl Acad Sci USA. 2010; 107:10109-10114. [PubMed: 20479231]

Cetin Y. Enterochromaffin (EC-(cells of the mammalian gastroenteropancreatic (GEP) endocrine system—cellular sources of prodynorphin-derived peptides. Cell Tissue Res. 1988; 253:173-179. [PubMed: 2901290]

Chang C-F, Serra R. Ift88 regulates Hedgehog signaling, Sfrp5 expression, and beta-catenin activity in post-natal growth plate. J Orthop Res. 2013; 31:350-356. [PubMed: 23034798]

Chetty-John S, Piwnica-Worms K, Bryant J, et al. Fibrocystic disease of liver and pancreas; underrecognized features of the X-linked ciliopathy oral-facial-digital syndrome type 1 (OFD I). Am J Med Genet Part A. 2010; 152A:2640-2645. [PubMed: 20818665]

Cleaver, O.; Melton, DA. Development of the endocrine pancreas. In: Kahn, CR.; Smith, RJ.; Jacobson, AM.; Weir, GC.; King, EL., editors. Joslin's Diabetes Mellitus. 14. Philadelphia, PA: Lippincott Williams and Wilkins; 2004. p. 21-40.

Clement CA, Ajbro KD, Koefoed K, et al. TGF- $\beta$ signaling is associated with endocytosis at the pocket region of the primary cilium. Cell Rep. 2013; 3:1806-1814. [PubMed: 23746451]

Cleveland MH, Sawyer JM, Afelik S, Jensen J, Leach SD. Exocrine ontogenies: On the development of pancreatic acinar, ductal and centroacinar cells. Sem Cell Dev Biol. 2012; 23:711-719.

Collin GB, Cyr E, Bronson R, et al. Alms1-disrupted mice recapitulate human Alstrom syndrome. Hum Mol Genet. 2005; 14:2323-2333. [PubMed: 16000322]

Corbit KC, Aanstad P, Singla V, et al. Vertebrate smoothened functions at the primary cilium. Nature. 2005; 437:1018-1021. [PubMed: 16136078]

Corbit KC, Shyer AE, Dowdle WE, et al. Kif3a constrains $\beta$-catenin-dependent Wnt signalling through dual ciliary and non-ciliary mechanisms. Nat Cell Biol. 2008; 10:70-76. [PubMed: 18084282]

Cras-Meneur C, Li L, Kopan R, Permutt MA. Presenilins, Notch dose control the fate of pancreatic endocrine progenitors during a narrow developmental window. Genes Dev. 2009; 23:2088-2101. [PubMed: 19723764]

Crisera CA, Rose MI, Connelly PR, et al. The ontogeny of TGF- $\beta 1,-\beta 2,-\beta 3$, and TGF- $\beta$ receptor-II expression in the pancreas: implications for regulation of growth and differentiation. J Pediatr Surg. 1999; 34:689-694. [PubMed: 10359165]

Dailey L, Ambrosetti D, Mansukhani A, Basilico C. Mechanisms underlying differential responses to FGF signaling. Cytokine Growth Factor Rev. 2005; 16:233-247. [PubMed: 15863038]

Dessimoz J, Bonnard C, Huelsken J, Grapin-Botton A. Pancreas-specific deletion of beta-catenin reveals Wnt-dependent and Wnt-independent functions during development. Curr Biol. 2005; 15:1677-1683. [PubMed: 16169491]

Deutsch G, Jung JN, Zheng MH, et al. A bipotential precursor population for pancreas and liver within the embryonic endoderm. Development. 2001; 128:871-881. [PubMed: 11222142]

di Magliano MP, Sekine S, Ermilov A, et al. Hedgehog/Ras interactions regulate early stages of pancreatic cancer. Genes Dev. 2006; 20:3161-3173. [PubMed: 17114586]

Dichmann DS, Miller CP, Jensen J, et al. Expression and misexpression of members of the FGF and TGF $\beta$ families of growth factors in the developing mouse pancreas. Dev Dyn. 2003; 226:663-674. [PubMed: 12666204]

Echelard Y, Epstein DJ, Stjacques B, et al. Sonic-hedgehog, a member of a family of putative signaling molecules, is implicated in the regulation of CNS polarity. Cell. 1993; 75:1417-1430. [PubMed: 7916661]

Elayat AA, Elnaggar MM, Tahir M. An immunocytochemical and morphometric study of the rat pancreatic-islets. J Anat. 1995; 186:629-637. [PubMed: 7559135]

Elghazi L, Cras-Meneur C, Czernichow P, Scharfmann R. Role for FGFR2IIIb-mediated signals in controlling pancreatic endocrine progenitor cell proliferation. Proc Natl Acad Sci USA. 2002; 99:3884-3889. [PubMed: 11891329]

Endoh-Yamagami S, Evangelista M, Wilson D, et al. The mammalian Cos2 homolog Kif7 plays an essential role in modulating Hh signal transduction during development. Curr Biol. 2009; 19:1320-1326. [PubMed: 19592253] 
Esteban MA, Harten SK, Tran MG, Maxwell PH. Formation of primary cilia in the renal epithelium is regulated by the von Hippel-Lindau tumor suppressor protein. J Am Soc Nephrol. 2006; 17:18011806. [PubMed: 16775032]

Ezratty EJ, Stokes N, Chai S, et al. A role for the primary cilium in notch signaling and epidermal differentiation during skin development. Cell. 2011; 145:1129-1141. [PubMed: 21703454]

Feijen A, Goumans MJ, van den AJ, Raaij E-V. Expression of activin subunits, activin receptors and follistatin in postimplantation mouse embryos suggests specific developmental functions for different activins. Development. 1994; 120:3621-3637. [PubMed: 7821227]

Feuillan PP, Ng D, Han JC, et al. Patients with Bardet-Biedl syndrome have hyperleptinemia suggestive of leptin resistance. J Clin Endocrinol Metab. 2011; 96:E528-E535. [PubMed: 21209035]

Fick GM, Johnson AM, Hammond WS, Gabow PA. Causes of death in autosomal dominant polycystic kidney-disease. J Am Soc Nephrol. 1995; 5:2048-2056. [PubMed: 7579053]

Finkelstein MM. The prevalence of diabetes among overweight and obese individuals is higher in poorer than in richer neighbourhoods. Can J Diabetes. 2008; 32:190-197.

Frank V, Habbig S, Bartram MP, et al. Mutations in NEK8 link multiple organ dysplasia with altered Hippo signalling and increased c-MYC expression. Hum Molr Genet. 2013; 22:2177-2185.

Fujikura J, Hosoda K, Kawaguchi Y, et al. Rbp-j regulates expansion of pancreatic epithelial cells and their differentiation into exocrine cells during mouse development. Dev Dyn. 2007; 236:2779_ 2791. [PubMed: 17849436]

Furukawa M, Eto Y, Kojima I. Expression of immunoreactive activin A in fetal rat pancreas. Endocr J. 1995; 42:63-68. [PubMed: 7599700]

Gallagher A-R, Esquivel EL, Briere TS, et al. Biliary and pancreatic dysgenesis in mice harboring a mutation in Pkhd1. Am J Pathol. 2008; 172:417-429. [PubMed: 18202188]

Gasa R, Mrejen C, Leachman N, et al. Proendocrine genes coordinate the pancreatic islet differentiation program in vitro. Proc Natl Acad Sci USA. 2004; 101:13245-13250. [PubMed: 15340143]

Gerdes JM, Liu Y, Zaghloul NA, et al. Disruption of the basal body comprises proteasomal function and perturbs intra-cellular Wnt response. Nat Genet. 2007; 39:1350-1360. [PubMed: 17906624]

Gerdes JM, Davis EE, Katsanis N. The vertebrate primary cilium in development, homeostasis, and disease. Cell. 2009; 137:32-45. [PubMed: 19345185]

Ghossoub R, Molla-Herman A, Bastin P, Benmerah A. The ciliary pocket: a once-forgotten membrane domain at the base of cilia. Biol Cell. 2011; 103:131-144. [PubMed: 21275905]

Girard D, Petrovsky N. Alstrom syndrome: insights into the pathogenesis of metabolic disorders. Nat Rev Endocrinol. 2011; 7:77-88. [PubMed: 21135875]

Githens S. The pancreatic duct cell-proliferative capabilities, specific characteristics, metaplasia, isolation, and culture. J Pediatr Gastroenterol Nutr. 1988; 7:486-506. [PubMed: 2456383]

Githens S. Pancreatic duct cell-cultures. Annu Rev Physiol. 1994; 56:419-443. [PubMed: 8010746]

Gittes GK. Developmental biology of the pancreas: a comprehensive review. Dev Biol. 2009; 326:435. [PubMed: 19013144]

Gittes GK, Galante PE, Hanahan D, et al. Lineage-specific morphogenesis in the developing pancreas: role of mesenchymal factors. Development. 1996; 122:439-447. [PubMed: 8625795]

Goodrich LV, Milenkovic L, Higgins KM, Scott MP. Altered neural cell fates and medulloblastoma in mouse patched mutants. Science. 1997; 277:1109-1113. [PubMed: 9262482]

Goto Y, Nomura M, Tanaka K, et al. Genetic interactions between activin type IIB receptor and Smad2 genes in asymmetrical patterning of the thoracic organs and the development of pancreas islets. Dev Dyn. 2007; 236:2865-2874. [PubMed: 17849440]

Grace C, Beales P, Summerbell C, et al. Energy metabolism in Bardet-Biedl syndrome. Int J Obes. 2003; $27: 1319-1324$.

Grantham JJ. Time to treat polycystic kidney diseases like the neoplastic disorders that they are. Kidney Int. 2000; 57:339-340. [PubMed: 10620217]

Grapin-Botton, A. Endoderm specification. Cambridge, MA: Harvard Stem Cell Institute; 2008. 
Green JS, Parfrey PS, Harnett JD, et al. The cardinal manifestations of Bardet-Biedl syndrome, a form of Laurence-Moon-Biedl syndrome. N Engl J Med. 1989; 321:1002-1009. [PubMed: 2779627]

Greider MH, Elliot DW. Election microscopy of human pancreatic tumors of islet cell origin. Am J Pathol. 1964; 44:663-678. [PubMed: 4291127]

Gresh L, Fischer E, Reimann A, et al. A transcriptional network in polycystic kidney disease. Embo J. 2004; 23:1657-1668. [PubMed: 15029248]

Gu GQ, Dubauskaite J, Melton DA. Direct evidence for the pancreatic lineage: NGN3+cells are islet progenitors and are distinct from duct progenitors. Development. 2002; 129:2447-2457. [PubMed: 11973276]

Gu GQ, Brown JR, Melton DA. Direct lineage tracing reveals the ontogeny of pancreatic cell fates during mouse embryogenesis. Mech Dev. 2003; 120:35-43. [PubMed: 12490294]

Harmon EB, Apelqvist AA, Smart NG, et al. GDF11 modulates NGN3(+) islet progenitor cell number and promotes beta-cell differentiation in pancreas development. Development. 2004; 131:61636174. [PubMed: 15548585]

Hart A, Papadopoulou S, Edlund H. Fgf10 maintains notch activation, stimulates proliferation, and blocks differentiation of pancreatic epithelial cells. Dev Dyn. 2003; 228:185-193. [PubMed: 14517990]

Haycraft CJ, Banizs B, Aydin-Son Y, et al. Gli2 and Gli3 localize to cilia and require the intraflagellar transport protein polaris for processing and function. Plos Genet. 2005; 1:480-488.

He X, Semenov M, Tamai K, Zeng X. LDL receptor-related proteins 5 and 6 in Wnt/beta-catenin signaling: arrows point the way. Development. 2004; 131:1663-1677. [PubMed: 15084453]

Hearn T, Spalluto C, Phillips VJ, et al. Subcellular localization of ALMS1 supports involvement of centrosome and basal body dysfunction in the pathogenesis of obesity, insulin resistance, and type 2 diabetes. Diabetes. 2005; 54:1581-1587. [PubMed: 15855349]

Hebrok M. Hedgehog signaling in pancreas development. Mech Dev. 2003; 120:45-57. [PubMed: 12490295]

Hebrok M, Kim SK, Melton DA. Notochord repression of endodermal Sonic hedgehog permits pancreas development. Genes Dev. 1998; 12:1705-1713. [PubMed: 9620856]

Hebrok M, Kim SK, St-Jacques B, et al. Regulation of pancreas development by hedgehog signaling. Development. 2000; 127:4905-4913. [PubMed: 11044404]

Hegyi P, Petersen O. The exocrine pancreas: The acinarductal tango in physiology and pathophysiology. Rev Physiol Biochem Pharmacol. 2013; 165:1-30. [PubMed: 23881310]

Heiser PW, Lau J, Taketo MM, et al. Stabilization of beta-catenin impacts pancreas growth. Development. 2006; 133:2023-2032. [PubMed: 16611688]

Heller RS, Dichmann DS, Jensen J, et al. Expression patterns of Wnts, Frizzleds, sFRPs, and misexpression in transgenic mice suggesting a role for Wnts in pancreas and foregut pattern formation. Dev Dyn. 2002; 225:260-270. [PubMed: 12412008]

Hellman B, Wallgren A, Hellerstrom C. Two types of islet alpha cells in different parts of the pancreas of the dog. Nature. 1962; 194:1201-1202. [PubMed: 13906278]

Herrera PL, Nepote V, Delacour A. Pancreatic cell lineage analyses in mice. Endocrine. 2002; 19:267277. [PubMed: 12624426]

Hezel AF, Kimmelman AC, Stanger BZ, et al. Genetics and biology of pancreatic ductal adenocarcinoma. Genes Dev. 2006; 20:1218-1249. [PubMed: 16702400]

Hong S-K, Dawid IB. FGF-dependent left-right asymmetry patterning in zebrafish is mediated by Ier2 and Fibp1. Proc Natl Acad Sci USA. 2009; 106:2230-2235. [PubMed: 19164561]

Hsieh JC, Rattner A, Smallwood PM, Nathans J. Biochemical characterization of Wnt-Frizzled interactions using a soluble, biologically active vertebrate Wnt protein. Proc Natl Acad Sci USA. 1999; 96:3546-3551. [PubMed: 10097073]

Huang F, Chen Y-G. Regulation of TGF-beta receptor activity. Cell Biosci. 2012; 2:9. [PubMed: 22420375]

Hui CC, Slusarski D, Platt KA, et al. Expression of 3 mouse homologs of the Drosophila segment polarity gene cubitus-interruptus, Gli, Gli-2, and Gli-3, in ectoderm-derived and mesoderm- 
derived tissues suggests multiple roles during postimplantation development. Dev Biol. 1994; 162:402-413. [PubMed: 8150204]

Igarashi P, Somlo S. Genetics and pathogenesis of polycystic kidney disease. J Am Soc Nephrol. 2002; 13:2384-2398. [PubMed: 12191984]

Ingham P. Hedgehog signalling. Curr Biol. 2008; 18:R238-R241. [PubMed: 18364223]

Ingham PW, McMahon AP. Hedgehog signaling in animal development: paradigms and principles. Genes Dev. 2001; 15:3059-3087. [PubMed: 11731473]

Ivliev AE, t Hoen PAC, van Roon-Mom WMC, et al. Exploring the transcriptome of ciliated cells using in silico dissection of human tissues. Plos One. 2012; 7:e35618. [PubMed: 22558177]

Jacquemin P, Yoshitomi H, Kashima Y, et al. An endothelial-mesenchymal relay pathway regulates early phases of pancreas development. Dev Biol. 2006; 290:189-199. [PubMed: 16386727]

Jensen J, Pedersen EE, Galante P, et al. Control of endodermal endocrine development by Hes-1. Nat Genet. 2000; 24:36-44. [PubMed: 10615124]

Jeon J, Correa-Medina M, Ricordi C, et al. Endocrine Cell Clustering During Human Pancreas Development. J Histochem Cytochem. 2009; 57:811-824. [PubMed: 19365093]

Johansson KA, Grapin-Botton A. Development and diseases of the pancreas. Clin Genet. 2002; 62:1423. [PubMed: 12123481]

Jørgensen MC, Ahnfelt-Rønne J, Hald J, et al. An illustrated review of early pancreas development in the mouse. Endocr Rev. 2007; 28:685-705. [PubMed: 17881611]

Kachar B, Taga R, Kniebel GA, Sesso A. Morphometric evaluation of the number of exocrine pancreatic cells during early postnatal growth in the rat. Acta Anat. 1979; 103:11-15. [PubMed: 371326]

Kaestner KH. Of cilia and cysts: modeling pancreatic polycystic disease. Gastroenterology. 2006; 130:926-928. [PubMed: 16530530]

Khokhar AS, Seidner DL. The pathophysiology of pancreatitis. Nutr Clin Pract. 2004; 19:5-15. [PubMed: 16215091]

Kikuchi Y, Trinh LA, Reiter JF, et al. The zebrafish bonnie and clyde gene encodes a mix family homeodomain protein that regulates the generation of endodermal precursors. Genes Dev. 2000; 14:1279-1289. [PubMed: 10817762]

Kim SK, Hebrok M. Intercellular signals regulating pancreas development and function. Genes Dev. 2001; 15:111-127. [PubMed: 11157769]

Kim SK, MacDonald RJ. Signaling and transcriptional control of pancreatic organogenesis. Curr Opin Genet Dev. 2002; 12:540-547. [PubMed: 12200159]

Kim SK, Hebrok M, Melton DA. Notochord to endoderm signaling is required for pancreas development. Development. 1997a; 124:4243-4252. [PubMed: 9334273]

Kim SK, Hebrok M, Melton DA. Pancreas development in the chick embryo. Cold Spring Harbor Symp Quant Biol. 1997b; 62:377-383. [PubMed: 9598372]

Kim SK, Hebrok M, Li E, et al. Activin receptor patterning of foregut organogenesis. Genes Dev. 2000; 14:1866-1871. [PubMed: 10921901]

Kim I, Ding T, Fu Y, et al. Conditional mutation of Pkd2 causes cystogenesis and upregulates betacatenin. J Am Soc Nephrol. 2009a; 20:2556-2569. [PubMed: 19939939]

Kim J, Kato M, Beachy PA. Gli2 trafficking links Hedgehog-dependent activation of smoothened in the primary cilium to transcriptional activation in the nucleus. Proc Natl Acad Sci USA. 2009b; 106:21666-21671. [PubMed: 19996169]

Kioussi C, Briata $\mathrm{P}$, Baek SH, et al. Identification of a Wnt/ Dvl/ $\beta$-catenin $\rightarrow$ Pitx 2 pathway mediating cell-type-specific proliferation during development. Cell. 2002; 111:673-685. [PubMed: 12464179]

Lacy PE. Electron microscopy of the normal islets of Langerhans; studies in the dog, rabbit, guinea pig and rat. Diabetes. 1957; 6:498-507. [PubMed: 13473645]

Lammert E, Brown J, Melton DA. Notch gene expression during pancreatic organogenesis. Mech Dev. 2000; 94:199-203. [PubMed: 10842072]

Landsman L, Parent A, Hebrok M. Elevated Hedgehog/Gli signaling causes beta-cell dedifferentiation in mice. Proc Natl Acad Sci USA. 2011; 108:17010-17015. [PubMed: 21969560] 
Larsson LI, Sundler F, Hakanson R, et al. Localization of APP, a postulated new hormone, to a pancreatic endocrine cell type. Histochemistry. 1974; 42:377-382. [PubMed: 4615088]

Larsson LI, Sundler F, Hakanson R. Immunohistochemical localization of human pancreatic polypeptide (HPP) to a population of islet cells. Cell Tissue Res. 1975; 156:167-171. [PubMed: 1091353]

Latif F, Tory K, Gnarra J, et al. Identification of the von Hippel-Lindau disease tumor suppressor gene. Science. 1993; 260:1317-1320. [PubMed: 8493574]

Le Bras S, Miralles F, Basmaciogullari A, et al. Fibroblast growth factor 2 promotes pancreatic epithelial cell proliferation via functional fibroblast growth factor receptors during embryonic life. Diabetes. 1998; 47:1236-1242. [PubMed: 9703323]

Lee MS, Gu DL, Feng LL, et al. Accumulation of extracellular-matrix and developmental dysregulation in the pancreas by transgenic production of transformting growth-factor-beta-1. Am J Pathol. 1995; 147:42-52. [PubMed: 7604884]

Lee N-C, Marsha JD, Collin GB, et al. Caloric restriction in alstrom syndrome prevents hyperinsulinemia. Am J Med Genet Part A. 2009; 149A:666-668. [PubMed: 19283853]

Lee BH, Liu J, Wong D, et al. Hyperactive neuroendocrine secretion causes size, feeding, and metabolic defects of C. elegans Bardet-Biedl syndrome mutants. Plos Biol. 2011; 9:e1001219. [PubMed: 22180729]

Leitch CC, Lodh S, Prieto-Echague V, Badano JL, Zaghloul NA. Basal body proteins regulate Notch signaling via endosomal trafficking. Journal of Cell Science. 2014 Mar 28. [Epub ahead of print].

Lewis J. Neurogenic genes and vertebrate neurogenesis. Curr Opin Neurobiol. 1996; 6:3-10. [PubMed: 8794055]

Li G, Vega R, Nelms K, et al. A role for Alstrom syndrome protein, Alms1, in kidney ciliogenesis and cellular quiescence. Plos Genet. 2007; 3:e8. [PubMed: 17206865]

Li Y, Rankin SA, Sinner D, Kenny AP, et al. Sfrp5 coordinates foregut specification and morphogenesis by antagonizing both canonical and noncanonical Wnt11 signaling. Genes Dev. 2008; 22:3050-3063. [PubMed: 18981481]

Like AA. The ultrastructure of the secretory cells of the islets of Langerhans in man. Lab Invest J Tech Methods Pathol. 1967; 16:937-951.

Lin FM, Hiesberger T, Cordes K, et al. Kidney-specific inactivation of the KIF3A subunit of kinesin-II inhibits renal ciliogenesis and produces polycystic kidney disease. Proc Natl Acad Sci USA. 2003; 100:5286-5291. [PubMed: 12672950]

Liu YP, Tsai IC, Morleo M, Oh EC, Leitch CC, Massa F, Lee BH, Parker DS, Finley D, Zaghloul NA, Franco B, Katsanis N. Ciliopathy proteins regulate paracrine signaling by modulating proteasomal degradation of mediators. Journal of Clinical Investigation. 2014 Apr 1. [Epub ahead of print].

Logan CY, Nusse R. The Wnt signaling pathway in development and disease. Annu Rev Cell Dev Biol. 2004; 20:781-810. [PubMed: 15473860]

Lolkema MP, Mans DA, Snijckers CM, et al. The von Hippel-Lindau tumour suppressor interacts with microtubules through kinesin-2. Febs Lett. 2007; 581:4571-4576. [PubMed: 17825299]

Lolkema MP, Mans DA, Ulfman LH, et al. Allele-specific regulation of primary cilia function by the von Hippel-Lindau tumor suppressor. Eur J Hum Genet. 2008; 16:73-78. [PubMed: 17912253]

Lopes SS, Lourenco R, Pacheco L, et al. Notch signalling regulates left-right asymmetry through ciliary length control. Development. 2010; 137:3625-3632. [PubMed: 20876649]

Lu WN, Peissel B, Babakhanlou H, et al. Perinatal lethality with kidney and pancreas defects in mice with a targetted Pkd1 mutation. Nat Genet. 1997; 17:179-181. [PubMed: 9326937]

Lutz MS, Burk RD. Primary cilium formation requires von Hippel-Lindau gene function in renalderived cells. Cancer Res. 2006; 66:6903-6907. [PubMed: 16849532]

Ma QF, Kintner C, Anderson DJ. Identification of neurogenin, a vertebrate neuronal determination gene. Cell. 1996; 87:43-52. [PubMed: 8858147]

Malaisse WJ. Non-invasive imaging of the endocrine pancreas (Review). Int J Mol Med. 2005; 15:243-246. [PubMed: 15647838] 
Maldonado TS, Kadison AS, Crisera CA, et al. Ontogeny of activin B and follistatin in developing embryonic mouse pancreas: implications for lineage selection. J Gastrointest Surg. 2000; 4:269_ 275. [PubMed: 10769089]

Mansouri A. Development and regeneration in the endocrine pancreas. ISRN Endocrinol. 2012; 2012:640956-640956. [PubMed: 23326678]

Mao JH, Wang JY, Liu B, et al. Low-density lipoprotein receptor-related protein-5 binds to Axin and regulates the canonical Wnt signaling pathway. Mol Cell. 2001; 7:801-809. [PubMed: 11336703]

Marigo V, Johnson RL, Vortkamp A, Tabin CJ. Sonic hedgehog differentially regulates expression of GLI and GLI3 during limb development. Dev Biol. 1996; 180:273-283. [PubMed: 8948590]

Marion V, Mockel A, De Melo C, et al. BBS-Induced Ciliary Defect Enhances Adipogenesis, Causing Paradoxical Higher-Insulin Sensitivity, Glucose Usage, and Decreased Inflammatory Response. Cell Metab. 2012; 16:363-377. [PubMed: 22958920]

Marshall JD, Bronson RT, Collin GB, et al. New Alstrom syndrome phenotypes based on the evaluation of 182 cases. Archives of Internal Medicine. 2005; 165(6):675-683. [PubMed: 15795345]

Marshall JD, Beck S, Maffei P, Naggert JK. Alstrom syndrome. Eur J Hum Genet. 2007; 15:11931202. [PubMed: 17940554]

Marshall JD, Maffei P, Collin GB, Naggert JK. Alstrom Syndrome: genetics and clinical overview. Curr Genomics. 2011; 12:225-235. [PubMed: 22043170]

McClish R, Eglitis J. Distribution of the A and B cells and of the islets (langerhans) in the duck pancreas. Ohio J Sci. 1969; 69:285-293.

McLin VA, Rankin SA, Zorn AM. Repression of Wnt/beta-catenin signaling in the anterior endoderm is essential for liver and pancreas development. Development. 2007; 134:2207-2217. [PubMed: 17507400]

McMahon AP, Ingham PW, Tabin CJ. Developmental roles and clinical significance of hedgehog signaling. Curr Top Dev Biol. 2003; 53:1-114. [PubMed: 12509125]

Miralles F, Czernichow P, Scharfmann R. Follistatin regulates the relative proportions of endocrine versus exocrine tissue during pancreatic development. Development. 1998; 125:1017-1024. [PubMed: 9463348]

Miralles F, Lamotte L, Couton D, Joshi RL. Interplay between FGF10 and Notch signalling is required for the self-renewal of pancreatic progenitors. Int J Dev Biol. 2006; 50:17-26. [PubMed: 16323074]

Mohammadi M, Olsen SK, Ibrahimi OA. Structural basis for fibroblast growth factor receptor activation. Cytokine Growth Factor Rev. 2005; 16:107-137. [PubMed: 15863029]

Mokdad AH, Ford ES, Bowman BA, et al. Prevalence of obesity, diabetes, and obesity-related health risk factors, 2001. J Am Med Assoc. 2003; 289:76-79.

Molla-Herman A, Ghossoub R, Blisnick T, et al. The ciliary pocket: an endocytic membrane domain at the base of primary and motile cilia. J Cell Sci. 2010; 123:1785-1795. [PubMed: 20427320]

Moore SJ, Green JS, Fan YL, et al. Clinical and genetic epidemiology of Bardet-Biedl syndrome in Newfoundland: a 22-year prospective, population-based, cohort study. Am J Med Genet Part A. 2005; 132A:352-360. [PubMed: 15637713]

Morgan D, Eley L, Sayer J, et al. Expression analyses and interaction with the anaphase promoting complex protein Apc2 suggest a role for inversin in primary cilia and involvement in the cell cycle. Hum Mol Genet. 2002; 11:3345-3350. [PubMed: 12471060]

Munger BL. A light and electron microscopic study of cellular differentiation in the pancreatic islets of the mouse. Am J Anat. 1958; 103:275-311. [PubMed: 13636992]

Murtaugh LC. The what, where, when and how of Wnt/ beta-catenin signaling in pancreas development. Organogenesis. 2008; 4:81-86. [PubMed: 18953422]

Murtaugh LC, Law AC, Dor Y, Melton DA. $\beta$-Catenin is essential for pancreatic acinar but not islet development. Development. 2005; 132:4663-4674. [PubMed: 16192304]

Nauli SM, Zhou J. Polycystins and mechanosensation in renal and nodal cilia. Bioessays. 2004; 26:844-856. [PubMed: 15273987] 
Nauli SM, Alenghat FJ, Luo Y, et al. Polycystins 1 and 2 mediate mechanosensation in the primary cilium of kidney cells. Nat Genet. 2003; 33:129-137. [PubMed: 12514735]

Neugebauer JM, Amack JD, Peterson AG, et al. FGF signalling during embryo development regulates cilia length in diverse epithelia. Nature. 2009; 458:651-654. [PubMed: 19242413]

Nicolau C, Torra R, Bianchi L, et al. Abdominal sonographic study of autosomal dominant polycystic kidney disease. J Clin Ultrasound. 2000; 28:277-282. [PubMed: 10867665]

Nielsen SK, Mollgard K, Clement CA, et al. Characterization of primary cilia and hedgehog signaling during development of the human pancreas and in human pancreatic duct cancer cell lines. Dev Dyn. 2008; 237:2039-2052. [PubMed: 18629868]

Norgaard GA, Jensen JN, Jensen J. FGF10 signaling maintains the pancreatic progenitor cell state revealing a novel role of Notch in organ development. Dev Biol. 2003; 264:323-338. [PubMed: 14651921]

Nusslein-Volhard C, Wieschaus E. Mutations affecting segment number and polarity in Drosophila. Nature. 1980; 287:795-801. [PubMed: 6776413]

Ogawa K, Abe K, Kurosawa N, et al. Expression of $\alpha, \beta \mathrm{A}$ and $\beta \mathrm{B}$ subunits of inhibin or activin and follistatin in rat pancreatic islets. FEBS Lett. 1993; 319:217-220. [PubMed: 8458412]

Ohuchi H, Hori Y, Yamasaki M, et al. FGF10 acts as a major ligand for FGF receptor 2 IIIb in mouse multi-organ development. Biochem Biophys Res Commun. 2000; 277:643-649. [PubMed: 11062007]

Ong ACM, Wheatley DN. Polycystic kidney disease — the ciliary connection. The Lancet. 2003; 361:774-776.

Pan FC, Wright C. Pancreas organogenesis: from bud to plexus to gland. Dev Dyn. 2011; 240:530565. [PubMed: 21337462]

Pandol, SJ. The exocrine pancreas. San Rafael, CA: Morgan \& Claypool Life Sciences; 2011. p. 1-64.

Papadopoulou S, Edlund H. Attenuated Wnt signaling perturbs pancreatic growth but not pancreatic function. Diabetes. 2005; 54:2844-2851. [PubMed: 16186384]

Parsons MJ, Pisharath H, Yusuff S, et al. Notch-responsive cells initiate the secondary transition in larval zebrafish pancreas. Mech Dev. 2009; 126:898-912. [PubMed: 19595765]

Pazour GJ, Dickert BL, Vucica Y, et al. Chlamydomonas IFT88 and its mouse homologue, polycystic kidney disease gene $\mathrm{Tg} 737$, are required for assembly of cilia and flagella. J Cell Biol. 2000; 151:709-718. [PubMed: 11062270]

Pedersen AH, Heller RS. A possible role for the canonical Wnt pathway in endocrine cell development in chicks. Biochem Biophys Res Commun. 2005; 333:961-968. [PubMed: 15970275]

Pierreux CE, Poll AV, Kemp CR, et al. The transcription factor hepatocyte nuclear factor- 6 controls the development of pancreatic ducts in the mouse. Gastroenterology. 2006; 130:532-541. [PubMed: 16472605]

Pilcher KE, Krieg PA. Expression of the Wnt inhibitor, sFRP5, in the gut endoderm of Xenopus. Gene Expr Patterns. 2002; 2:369-372. [PubMed: 12617827]

Pirro N, Sielezneff I, Ouaissi M, et al. Coelioscopic treatment of pancreatic polycystic disease. Ann Chirurgie. 2003; 128:109-111.

Poole CA, Flint MH, Beaumont BW. Analysis of the morphology and function of primary cilia in connective tissues: a cellular cybernetic probe? Cell Motil. 1985; 5:175-193. [PubMed: 4005941]

Quinn AR, Blanco CL, Perego C, et al. The ontogeny of the endocrine pancreas in the fetal/newborn baboon. J Endocrinol. 2012; 214:289-299. [PubMed: 22723715]

Radtke F, Raj K. The role of Notch in tumorigenesis: oncogene or tumour suppressor? Nat Rev Cancer. 2003; 3:756-767. [PubMed: 14570040]

Rahier J, Wallon J, Henquin JC. Cell populations in the endocrine pancreas of human neonates and infants. Diabetologia. 1981; 20:540-546. [PubMed: 6116638]

Ramalho-Santos M, Melton DA, McMahon AP. Hedgehog signals regulate multiple aspects of gastrointestinal development. Development. 2000; 127:2763-2772. [PubMed: 10821773]

Rattner JB, Sciore P, Ou Y, et al. Primary cilia in fibroblast-like type B synoviocytes lie within a cilium pit: a site of endocytosis. Histol Histopathol. 2010; 25:865-875. [PubMed: 20503175] 
Reichert M, Rustgi AK. Pancreatic ductal cells in development, regeneration, and neoplasia. J Clin Invest. 2011; 121:4572-4578. [PubMed: 22133881]

Revest JM, Spencer-Dene B, Kerr K, et al. Fibroblast growth factor receptor 2-IIIb acts upstream of Shh and Fgf4 and is required for limb bud maintenance but not for the induction of Fgf8, Fgf10, Msx1, or Bmp4. Dev Biol. 2001; 231:47-62. [PubMed: 11180951]

Ritvos O, Tuuri T, Eramaa M, et al. Activin disrupts epithelial branching morphogenesis in developing glandular organs of the mouse. Mech Dev. 1995; 50:229-245. [PubMed: 7619733]

Rohatgi R, Milenkovic L, Scott MP. Patched1 regulates Hedgehog signaling at the primary cilium. Science. 2007; 317:372-376. [PubMed: 17641202]

Ruppert JM, Kinzler KW, Wong AJ, et al. The GLI-Kruppel family of human genes. Mol Cell Biol. 1988; 8:3104-3113. [PubMed: 2850480]

Sanvito F, Nichols A, Herrera PL, et al. TGF-beta 1 overexpression in murine pancreas induces chronic pancreatitis and together with TNF-alpha, triggers insulin-dependent diabetes. Biochem Biophys Res Commun. 1995; 217:1279-1286. [PubMed: 8554587]

Sasaki H, Nishizaki Y, Hui CC. Regulation of Gli2 and Gli3 activities by an amino-terminal repression domain: implication of Gli2 and Gli3 as primary mediators of Shh signaling. Development. 1999; 126:3915-3924. [PubMed: 10433919]

Schermer B, Ghenoiu C, Bartram M, et al. The von Hippel-Lindau tumor suppressor protein controls ciliogenesis by orienting microtubule growth. J Cell Biol. 2006; 175:547-554. [PubMed: 17101696]

Schlessinger J. Cell signaling by receptor tyrosine kinases. Cell. 2000; 103:211-225. [PubMed: 11057895]

Schneider L, Clement CA, Teilmann SC, et al. PDGFR $a a$ signaling is regulated through the primary cilium in fibroblasts. Curr Biol. 2005; 15:1861-1866. [PubMed: 16243034]

Schweisguth F. Regulation of notch signaling activity. Curr Biol. 2004; 14:R129-R138. [PubMed: 14986688]

Schweitzer R, Vogan KJ, Tabin CJ. Similar expression and regulation of Gli2 and Gli3 in the chick limb bud. Mech Dev. 2000; 98:171-174. [PubMed: 11044624]

Seeley ES, Carrière C, Goetze T, et al. Pancreatic cancer and precursor pancreatic intraepithelial neoplasia lesions are devoid of primary cilia. Cancer Res. 2009; 69:422-430. [PubMed: 19147554]

Shen HCJ, Adem A, Ylaya K, et al. Deciphering von Hippel-Lindau (VHL/Vhl)-associated pancreatic manifestations by inactivating vhl in specific pancreatic cell populations. Plos One. 2009; 4:e4897. [PubMed: 19340311]

Sherafat-Kazemzadeh R, Ivey L, Kahn SR, et al. Hyperphagia among patients with Bardet-Biedl syndrome. Pediatr Obes. 2013; 8:E64-E67. [PubMed: 23776152]

Shi YG, Massague J. Mechanisms of TGF-beta signaling from cell membrane to the nucleus. Cell. 2003; 113:685-700. [PubMed: 12809600]

Shih HP, Kopp JL, Sandhu M, et al. A Notch-dependent molecular circuitry initiates pancreatic endocrine and ductal cell differentiation. Development. 2012; 139:2488-2499. [PubMed: 22675211]

Shih HP, Wang A, Sander M. Pancreas organogenesis: from lineage determination to morphogenesis. Annu Rev Cell Dev Biol. 2013; 29:81-105. [PubMed: 23909279]

Shiozaki S, Tajima T, Zhang YQ, et al. Impaired differentiation of endocrine and exocrine cells of the pancreas in transgenic mouse expressing the truncated type II activin receptor. Biochim Biophys Acta Mol Cell Res. 1999; 1450:1-11.

Simons M, Gloy J, Ganner A, et al. Inversin, the gene product mutated in nephronophthisis type II, functions as a molecular switch between Wnt signaling pathways. Nat Genet. 2005; 37:537-543. [PubMed: 15852005]

Smart NG, Apelqvist AA, Gu XY, et al. Conditional expression of Smad7 in pancreatic beta cells disrupts TGF-beta signaling and induces reversible diabetes mellitus. Plos Biol. 2006; 4:200 209.

Sommer L, Ma QF, Anderson DJ. Neurogenins, a novel family of atonal-related bHLH transcription factors, are putative mammalian neuronal determination genes that reveal progenitor cell 
heterogeneity in the developing CNS and PNS. Mol Cell Neurosci. 1996; 8:221-241. [PubMed: 9000438]

Sorokin S. Centrioles and the formation of rudimentary cilia by fibroblasts and smooth muscle cells. J Cell Biol. 1962; 15:363-377. [PubMed: 13978319]

Stafford D, Prince VE. Retinoic acid signaling is required for a critical early step in zebrafish pancreatic development. Curr Biol. 2002; 12:1215-1220. [PubMed: 12176331]

Stefan Y, Grasso S, Perrelet A, Orci L. A quantitative immunofluorescent study of the endocrine cell populations in the developing human pancreas. Diabetes. 1983; 32:293-301. [PubMed: 6131849]

Steiner DJ, Kim A, Miller K, Hara M. Pancreatic islet plasticity interspecies comparison of islet architecture and composition. Islets. 2010; 2:135-145. [PubMed: 20657742]

Stuckenholz C, Lu L, Thakur PC, et al. Sfrp5 modulates both Wnt and BMP signaling and regulates gastrointestinal organogensis in the zebrafish, Danio rerio. Plos One. 2013; 8:e62470. [PubMed: 23638093]

Tamai K, Semenov M, Kato Y, et al. LDL-receptor-related proteins in Wnt signal transduction. Nature. 2000; 407:530-535. [PubMed: 11029007]

Tang, W-b; Ling, G-h; Sun, L.; Liu, F-Y. Smad anchor for receptor activation (SARA) in TGF-beta signaling. Front Biosci (Elite edition). 2010; 2:857-860.

Taulman PD, Haycraft CJ, Balkovetz DF, Yoder BK. Polaris, a protein involved in left-right axis patterning, localizes to basal bodies and cilia. Mol Biol Cell. 2001; 12:589-599. [PubMed: 11251073]

Tiso N, Moro E, Argenton F. Zebrafish pancreas development. Mol Cell Endocrinol. 2009; 312:24-30. [PubMed: 19477220]

Torra R, Nicolau C, Badenas C, et al. Ultrasonographic study of pancreatic cysts in autosomal dominant polycystic kidney disease. Clin Nephrol. 1997; 47:19-22. [PubMed: 9021236]

Tremblay KD, Hoodless PA, Bikoff EK, Robertson EJ. Formation of the definitive endoderm in mouse is a Smad2-dependent process. Development. 2000; 127:3079-3090. [PubMed: 10862745]

Umbhauer M, Djiane A, Goisset C, et al. The C-terminal cytoplasmic Lys-Thr-X-X-X-Trp motif in frizzled receptors mediates Wnt/beta-catenin signalling. Embo J. 2000; 19:4944-4954. [PubMed: 10990458]

Urban AE, Zhou X, Ungos JM, et al. FGF is essential for both condensation and mesenchymalepithelial transition stages of pronephric kidney tubule development. Dev Biol. 2006; 297:103117. [PubMed: 16872594]

van Asselt SJ, de Vries EG, van Dullemen HM, et al. Pancreatic cyst development: insights from von Hippel-Lindau disease. Cilia. 2013; 2:3. [PubMed: 23384121]

Verschueren K, Dewulf N, Goumans M-J, et al. Expression of type I and type IB receptors for activin in midgestation mouse embryos suggests distinct functions in organogenesis. Mech Dev. 1995; 52:109-123. [PubMed: 7577669]

Wang S, Yan J, Anderson DA, et al. Neurog3 gene dosage regulates allocation of endocrine and exocrine cell fates in the developing mouse pancreas. Dev Biol. 2010; 339:26-37. [PubMed: 20025861]

Ware SM, Aygun MG, Hildebrandt F. Spectrum of clinical diseases caused by disorders of primary cilia. Proc Am Thorac Soc. 2011; 8:444-450. [PubMed: 21926397]

Wells JM, Esni F, Boivin GP, et al. Wnt/beta-catenin signaling is required for development of the exocrine pancreas. BMC Dev Biol. 2007; 7:4. [PubMed: 17222338]

Wierup N, Sundler F, Heller S. The islet ghrelin cell. J Mol Endocrinol. 2013; 15:R35-R49. [PubMed: 24049065]

Wierup N, Svensson H, Mulder H, Sundler F. The ghrelin cell: a novel developmentally regulated islet cell in the human pancreas. Regul Pept. 2002; 107:63-69. [PubMed: 12137967]

Wigley WC, Fabunmi RP, Lee MG, et al. Dynamic association of proteasomal machinery with the centrosome. J Cell Biol. 1999; 145:481-490. [PubMed: 10225950]

Wolfe-Coote SA, Louw J, Dutoit DF. Preliminary-observations of the co-existence of regulatory peptides in cells of the baboon endocrine pancreas. Experientia. 1988; 44:238-240. [PubMed: 3280339] 
Wu GQ, Markowitz GS, Li L, et al. Cardiac defects and renal failure in mice with targeted mutations in Pkd2. Nat Genet. 2000; 24:75-78. [PubMed: 10615132]

Yamamoto M, Kataoka K. Electron microscopic observation of the primary cilium in the pancreatic islets. Arch Histol Jpn. 1986; 49:449-457. [PubMed: 3545133]

Yamaoka T, Idehara C, Yano M, et al. Hypoplasia of pancreatic islets in transgenic mice expressing activin receptor mutants. J Clin Invest. 1998; 102:294-301. [PubMed: 9664070]

YangSnyder J, Miller JR, Brown JD, et al. A frizzled homolog functions in a vertebrate Wnt signaling pathway. Curr Biol. 1996; 6:1302-1306. [PubMed: 8939578]

Yerian LM, Brady L, Hart J. Hepatic manifestations of Jeune syndrome (asphyxiating thoracic dystrophy). Sem Liver Dis. 2003; 23:195-200.

Yoder BK, Tousson A, Millican L, et al. Polaris, a protein disrupted in orpk mutant mice, is required for assembly of renal cilium. Am J Physiol Renal Physiol. 2002; 282:F541-F552. [PubMed: 11832437]

Zhang Q, Davenport JR, Croyle MJ, et al. Disruption of IFT results in both exocrine and endocrine abnormalities in the pancreas of Tg737orpk mutant mice. Lab Invest. 2005; 85:45-64. [PubMed: 15580285]

Zhang XQ, Ibrahimi OA, Olsen SK, et al. Receptor specificity of the fibroblast growth factor familythe complete mammalian FGF family. J Biol Chem. 2006; 281:15694-15700. [PubMed: 16597617]

Zhang H, Ables ET, Pope CF, et al. Multiple, temporal-specific roles for HNF6 in pancreatic endocrine and ductal differentiation. Mech Dev. 2009; 126:958-973. [PubMed: 19766716]

Zong Y, Panikkar A, Xu J, et al. Notch signaling controls liver development by regulating biliary differentiation. Development. 2009; 136:1727-1739. [PubMed: 19369401]

Zorn AM, Wells JM. Vertebrate endoderm development and organ formation. Annu Rev Cell Dev Biol. 2009; 25:221-251. [PubMed: 19575677] 
A: Initiation of pancreas development

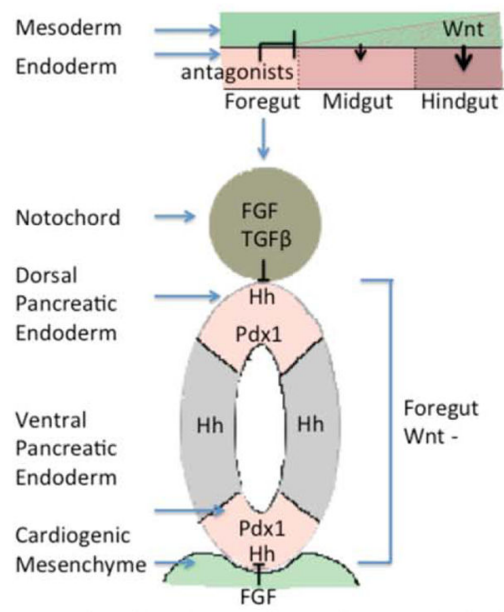

B. Interplay of signaling pathways during early development

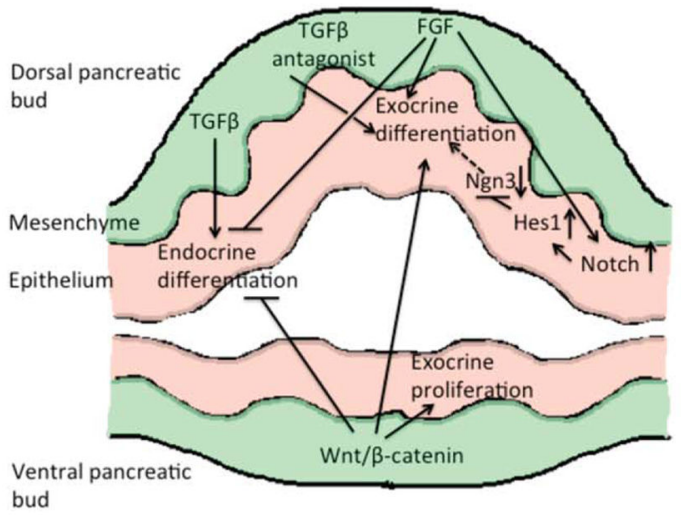

C. Cell fate determination during secondary transition

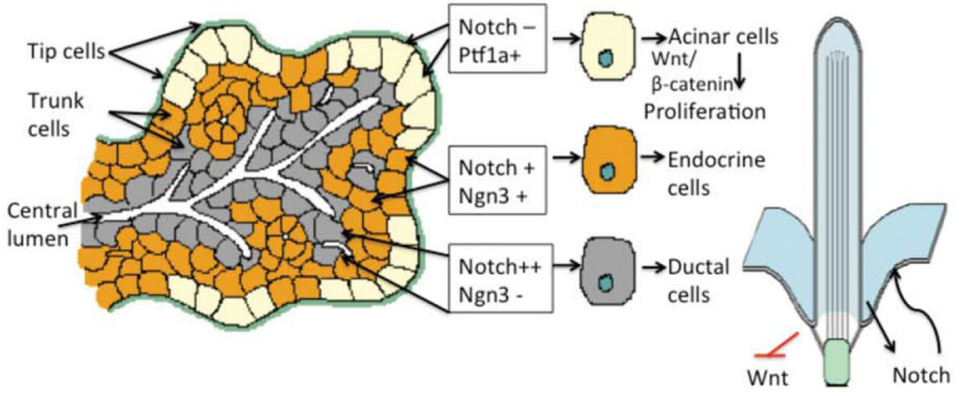

Possible ciliary role
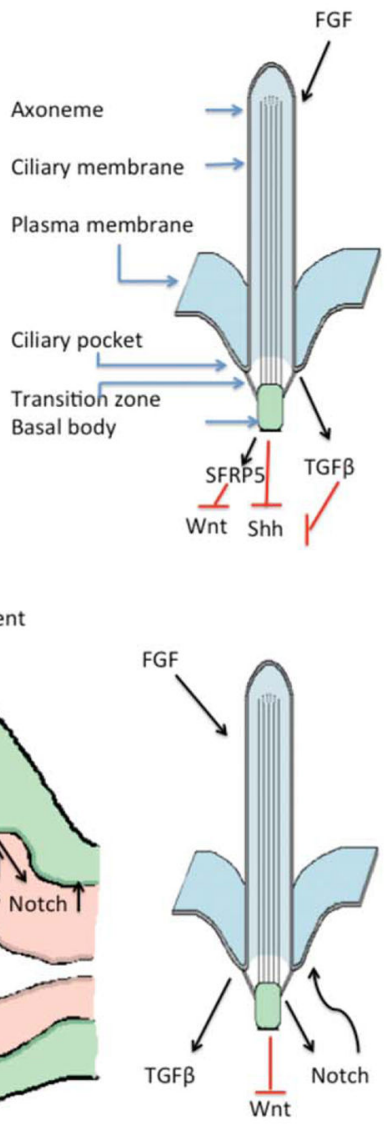

FIGURE 1.

Regulation of pancreatic development by cilia-dependent pathways. A. In early endodermal patterning, Wnt/ $\beta$-catenin signaling is excluded from the foregut endoderm by foregut expression of antagonists (McLin et al., 2007). The dorsal and ventral pancreatic endoderm of the foregut are subsequently specified by suppression of Shh signaling, as a result of FGF and TGF- $\beta$ signaling from the notochord (Hebrok et al., 1998) and FGF signaling from the cardiogenic mesenchyme (Deutsch et al., 2001). Expression of the pancreatic progenitor marker Pdx1 is upregulated throughout the pancreatic endoderm, specifying progenitor cells that will contribute to the mature organ. Primary cilia prevent improper activation of both 
canonical Wnt signaling (Gerdes et al., 2007; Corbit et al., 2008), as well as Shh (Cervantes et al., 2010), and are required for proper TGF- $\beta$ signaling (Clement et al., 2013), implicating proper ciliary function in the patterning of the gut endoderm and the specification of pancreatic progenitor cells. In addition, FGF signaling regulates the length of primary cilia (Brody et al., 2000; Bonnafe et al., 2004; Urban et al., 2006; Neugebauer et al., 2009), which blocks inappropriate activation of $\mathrm{Hh}$ signaling in pancreatic epithelium (Cervantes et al., 2010), suggesting that FGFs may repress $\mathrm{Hh}$ in pancreatic endoderm by maintaining cilia. B. The pancreatic epithelium, defined by Pdx 1 expression, evaginate to form dorsal and ventral pancreatic buds. Pdx $1+$ cells that lack Notch signaling transiently express Ngn3 and eventually give rise to endocrine cells. Those that retain Notch signaling express Ptf1a, repress Ngn3 expression, and give rise to exocrine cells (Gu et al., 2002; Herrera et al., 2002; Gu et al., 2003). Notch signaling is maintained by mesenchymal FGFs (Hart et al., 2003; Norgaard et al., 2003; Miralles et al., 2006), which favors exocrine differentiation over endocrine differentiation (Bhushan et al., 2001; Hart et al., 2003; Norgaard et al., 2003; Jacquemin et al., 2006). Canonical Wnt signaling is required for the proliferation of pancreatic progenitor cells (Dessimoz et al., 2005; Murtaugh et al., 2005; Papadopoulou and Edlund, 2005; Heiser et al., 2006; Wells et al., 2007), as well as for the exocrine acinar cells (Murtaugh et al., 2005; Wells et al., 2007). Primary cilia in the pancreas are necessary to preclude overactivation of Notch signaling, and therefore may regulate the balance between endocrine and exocrine fates (Cervantes et al., 2010). TGF- $\beta$ signaling from the surrounding mesenchyme is also important to drive production of endocrine fates from the pancreatic epithelium and inhibit exocrine fates. In contrast, canonical Wnt signaling is essential for the proliferation of acinar cells and preventing endocrine differentiation. Given the role of cilia in inhibiting Wnt signaling and promoting TGF- $\beta$ signaling, cilia may block improper Wnt signaling and promote TGF- $\beta$ in endocrine precursor cells. The absence of cilia in the main exocrine lineage, acinar cells, however, may serve the opposite function, providing an environment conducive to high levels of $\mathrm{Wnt} / \beta$-catenin signaling. $\mathbf{C}$. During the secondary transition of pancreatic development, tip cells at the termini of ducts give rise to exocrine acinar cells and trunk cells lining the ducts give rise to endocrine and ductal cells. Notch signaling regulates the balance between tip and trunk fates; active Notch promotes trunk identity and represses tip identity, and tip cells expressing low levels of Notch proliferate rapidly under the control of canonical Wnt signaling, ultimately producing acinar cells. Additionally, trunk cells maintain dual potential: high levels of Notch activity lead to the formation of duct cells through repression of Ngn3 and low levels of Notch enhance Ngn3 expression, driving differentiation of endocrine cells (Shih et al., 2012). Primary cilia may regulate these processes by coordinating regulation of Notch. 


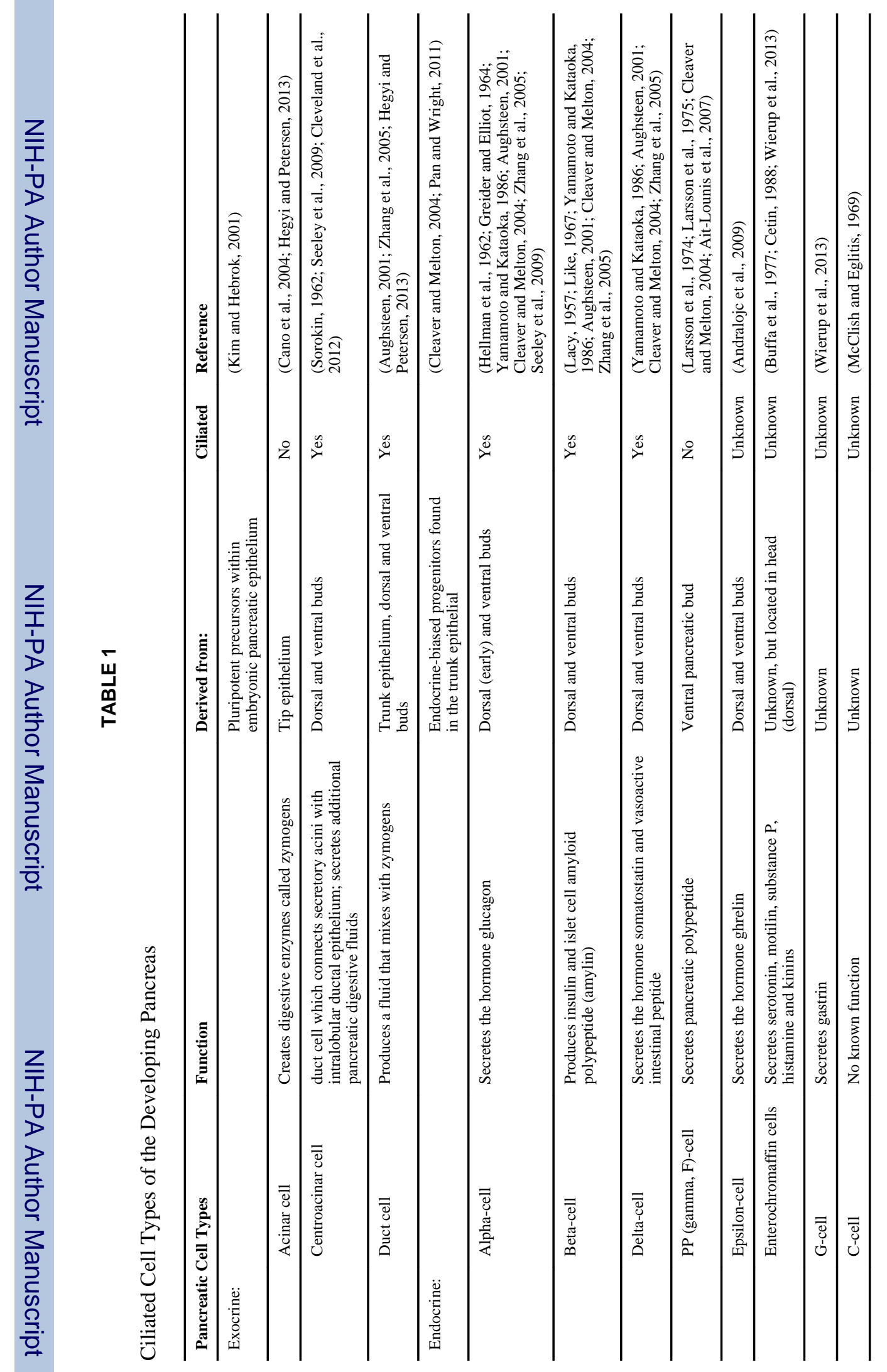

Birth Defects Res C Embryo Today. Author manuscript; available in PMC 2015 June 01. 


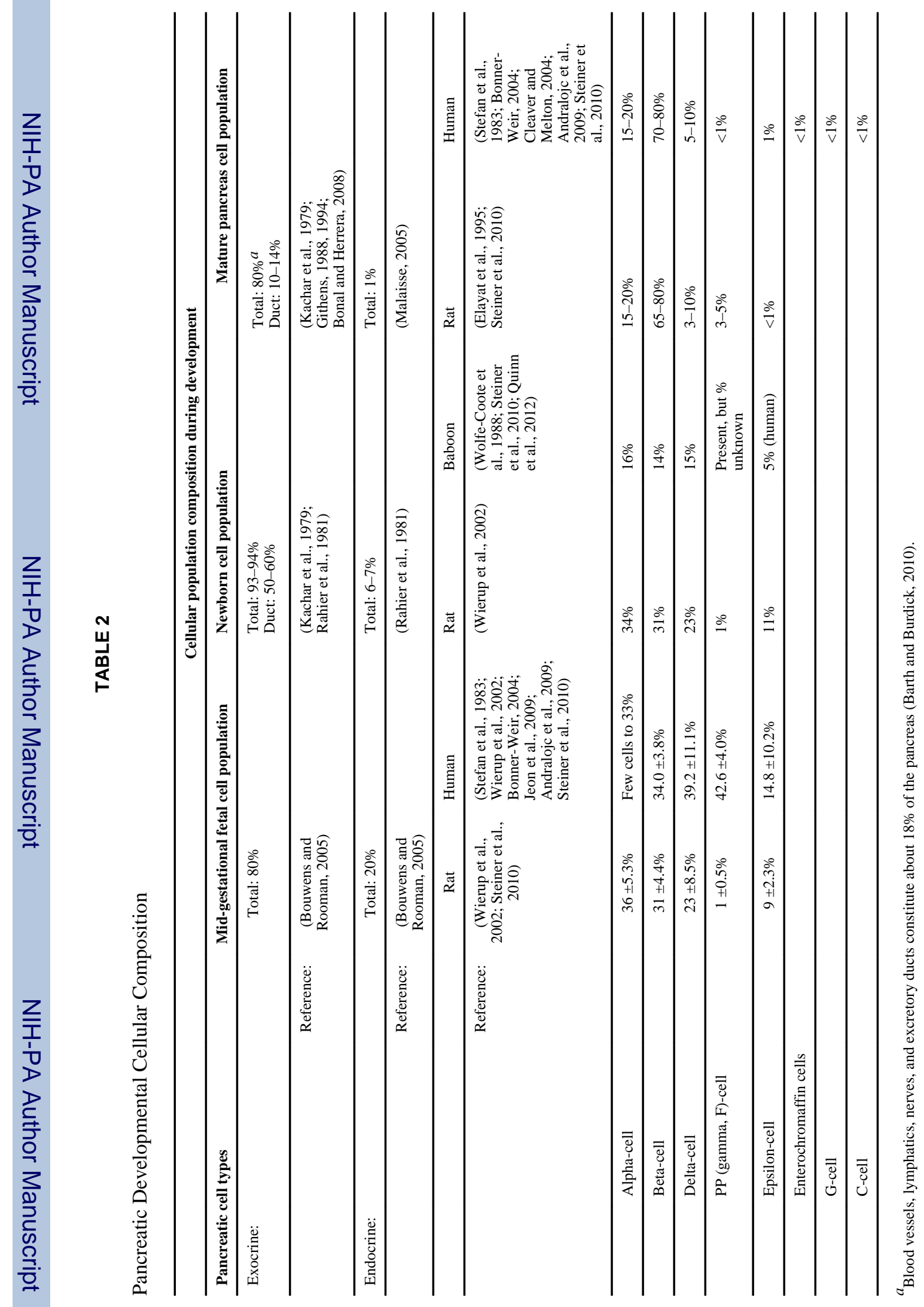

Birth Defects Res C Embryo Today. Author manuscript; available in PMC 2015 June 01. 